\title{
Sedimentation of overbank floods in the confined complex channel-floodplain system of the Lower Yellow River, China
}

\author{
Min Zhang ${ }^{1,2,3}$, He Qing Huang ${ }^{1,2 *}$, Paul A Carling ${ }^{4}$, Mingwu Zhang ${ }^{3}$
}

${ }^{1}$ Key Lab. of Water Cycle and Related Land Surface Processes, Institute of Geographical

Sciences and Natural Resources Research, Chinese Academy of Sciences, Beijing, 100101,

\section{China}

${ }^{2}$ College of Resources and Environment, University of the Chinese Academy of Sciences, Beijing, 100049, China

${ }^{3}$ Key Lab. of the Yellow River Sediment of the Ministry of Water Resources, Institute of Hydraulic Research, Yellow River Water Conservancy Commission, Zhengzhou, 450003, China

${ }^{4}$ Department of Geography and Environment, University of Southampton, University Road, Southampton, UK

*Corresponding to : huanghq@igsnrr.ac.cn

\section{Abstract:}

The channel boundary conditions along the Lower Yellow River (LYR) have been altered significantly since the 1950 s with the continual reinforcement and construction of both main and secondary dykes and river training works. To evaluate how the confined complex channel-floodplain system of the LYR responds to floods, this study presents a detailed investigation of the relationship between the tempo-spatial distribution of sedimentation/erosion and overbank floods occurred in the LYR. For large overbank floods, we found that when the sediment transport coefficient (ratio of sediment concentration of flow to flow discharge) is less than 0.034 , the bankfull channel is subject to significant erosion, while the main and secondary floodplains both accumulate sediment. The amount of sediment deposited on the main and secondary floodplains is closely related to the ratio of

This article has been accepted for publication and undergone full peer review but has not been through the copyediting, typesetting, pagination and proofreading process which may lead to differences between this version and the Version of Record. Please cite this article as doi: $10.1002 /$ hyp. 11260 
peak discharge to bankfull discharge, volume of water flowing over the floodplains and sediment concentration of overbank flow, while the degree of erosion in the bankfull channel is related to the amount of sediment deposited on the main and secondary floodplains, water volume and sediment load in flood season. The significant increase in erosion in the bankfull channel is due to the construction of the main and secondary dykes and river training works, which are largely in a wide and narrow alternated pattern along the LYR such that the water flowing over wider floodplains returns to the channel downstream after it drops sediment. For small overbank floods, the bankfull channel is subject to erosion when the sediment transport coefficient is less than 0.028 , while the amount of sediment deposited on the secondary floodplain is associated closely with the sediment concentration of flow. Over the entire length of the LYR, the situation of erosion in the bankfull channel and sediment deposition on the main and secondary floodplains occurred mainly in the upper reach of the LYR, in which a channel wandering in planform has been well developed.

Key words: Overbank floods; Channel-floodplain interaction; Sedimentation; Erosion; Lower Yellow River

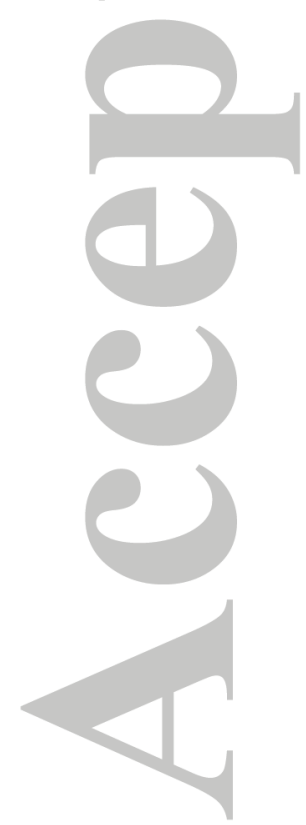




\section{Introduction}

Floodplains display diverse forms because they evolve from complex processes (Nanson and

Croke, 1992; Lewin et al., 2016). During these processes, anthropogenic influences on floodplain development have been of increasing concern, especially in lowland riverine areas (Newson, 1989; Parker, 1995; Hudson and Middelkoop, 2015). To assess the spatial distribution of sediment deposition in floodplains, numerical models, field sampling and surveys, and various mapping methods have commonly been applied (James, 1985; Pizzuto, 1987; Howard, 1992; Mertes, 1994; Dunne et al., 1998). Recently, dating methods have gained wide applications, with a focus on the evaluation of floodplain accumulation rates (He and Walling, 1996; Nicholas and Walling, 1997; Allison et al., 1998; Goodbred and Kuehl, 1998; Latrubesse and Franzinelli, 2002; Aalto et al., 2008; Day et al., 2008).

Floodplain sedimentation rates vary with the frequency, duration, magnitude and suspended sediment concentration of floods (Brown, 1983; James, 1985; Marriott, 1992; Asselman and Middlekoop, 1995; Gomez et al., 1995; Magilligan et al., 1998), the degree of river training (Wu et al., 2005), and many other factors (e.g., Aalto et al., 2003). When the effects of human activities are significant, however, very different floodplain sedimentation rates can be produced. In 1973 Mississippi River flood, floodplain deposition in Louisiana along the lower Mississippi ranged in thickness from 11 to $530 \mathrm{~mm}$ (Kesel et al., 1974). This is in contrast to the investigation of Benedetti (2003) who identified a regional mean rate of $1.4 \mathrm{~mm} \mathrm{yr}^{-1}$ over the last 2500 years for floodplain sedimentation in the upper Mississippi River. Although the short-term accretion rate of the floodplain in the lower Mississippi is much larger than the long-term averaged value, it appears declining in recent decades, 8.0 to 14.4 $\mathrm{mm} \mathrm{yr}^{-1}$ since 1954 and 4.4 to $14.2 \mathrm{~mm} \mathrm{yr}^{-1}$ since 1964 . The decreasing sedimentation rate reflects the growing practices of soil conservation in the upper Mississippi River basin over the last half-century (Benedetti, 2003). 
With the continual growth in human population and fast urbanization in many parts of the world, land has become much more valuable. To protect this valuable resource from flood inundation, a lot of river embankment activities have taken place in recent decades. This limits considerably the inundating space of large floods and yet results in much higher sedimentation rates on floodplains and much more complex channel-floodplain interactions (Newson, 1989; Parker, 1995; Wu et al., 2005; Hudson and Middelkoop, 2015). The Lower Yellow River (LYR) is a typical case of this kind and has been confined to a dyke-lined course over a length of $876 \mathrm{~km}$. Over the last 70 years much of the river management effort has been devoted to improving the capacity of flood prevention in the confined channel-floodplain system because the floodplains and riverbed all continue rising until the Xiaolangdi Dam started to impound water in 1999 (Wu et al., 2005). With the continual reinforcement of the main dykes since the 1950s and the construction of the secondary dikes by local farmers since the 1960s, the secondary floodplain has gained well development along most reaches of the LYR (Hu and Zhang, 2006; Hu et al., 2006). These changes in the river channel boundary have made it necessary to categorize overbank floods in the LYR into large and small types in terms of the possible extent of their inundation on the floodplains (Zhang et al., 2006; Yao et al., 2007). Large overbank floods are those during which floodwater reaches up to the main dykes, while during small overbank floods, floodwater reaches only as far as the secondary dykes, and does not inundate the floodplain beyond the secondary dykes.

To understand the complex channel-floodplain interaction of the LYR, a large number of studies have been conducted, focusing on the spatial distribution of sediment deposition during large floods (Liu et al., 1986; Shen et al., 2006; Yao et al., 2007; Hou et al., 2010; Li et al., 2011). Although significant advances have been made in previous studies, there has been an ongoing debate over the functions of overbank floods in the LYR. Some argued that 
overbank floods can result in "floodplain deposition and erosion in bankfull channel" and so are helpful to alleviate the present problem of the LYR, in which due to the construction of the secondary dykes a higher perched river channel has been developed from the already perched river. On the contrary, the others claimed that overbank floods do not always result in "floodplain deposition and erosion in bankfull channel", but may bring about sediment deposition not only on the main and secondary floodplains but also in the bankfull channel, which will exacerbate the perched situation of the LYR (e.g., Qi et al., 2005; Zhang et al., 2006). Typically, since 1986 both water and sediment input into the LYR have reduced dramatically due to the regulation of several large reservoirs constructed in the upper and middle basin and the long-term practice of water and soil conservation in the whole drainage basin. Meanwhile, overbank floods in the LYR occur much less frequently and with much smaller magnitudes than before (Xu, 2004; Chen et al., 2012; Xia et al., 2014). Proposals have been made recently for inputting more overbank floods to the LYR through regulating several large reservoirs so as to scour down the riverbed of the LYR and relatively build up higher floodplains (e.g., Hou et al., 2010; Zhang et al., 2016). To clarify the confusion over the effects of overbank floods in the confined complex channel-floodplain system of the LYR, this study presents a detailed investigation of the relationship between the tempo-spatial distribution of sedimentation/erosion and the types of overbank floods occurred in the LYR since the 1950s.

\section{Geomorphological characteristics of the Lower Yellow River}

The Yellow River flows into the North China Plain initially in an easterly direction and then following a northeastern course to the Bohai Sea (part of the Yellow Sea) (Fig. 1). The length of the Lower Yellow River (LYR) is $878 \mathrm{~km}$. Over the last 70 years, the riverbed of the LYR has experienced an intermittent rise due to sedimentation with an average rate of 5 100 
$\mathrm{mm} \mathrm{yr}^{-1}$ and on average the river bed at present is around 3-5 $\mathrm{m}$ higher than the level of the ground outside the main dykes, with some parts of the riverbed even more than $10 \mathrm{~m}$ higher than the ground where millions of people are living. This has resulted in a so-called "perched" or "hung" river (Fig. 2). The channel of the LYR at bankfull is wide in the upper reach and yet narrows to a considerable degree in the downstream reach, with a gradient steep upstream and gentle downstream. In terms of geomorphic features, the LYR has been divided into three reaches: upper, middle and lower. The upper reach is $299 \mathrm{~km} \mathrm{long}$, from the Xiaolangdi Dam (XLD) to Gaocun gauging station. Two major tributaries enter the Yellow River in this reach, the Qinhe River on the left bank and the Yiluohe River on the right bank. The spacing between the opposite main dykes that have been continuously reinforced since the $1950 \mathrm{~s}$ is $5-20 \mathrm{~km}$ in this reach. This reach exhibits a wandering river planform (Fig. 3), with a very wide and shallow channel at bankfull, in which a meandering streamline and numerous sandbars are subject to frequent migration due to continual sediment deposition (Qian and Zhou, 1965; Qian et al., 1987).

The middle reach of the LYR, $165 \mathrm{~km}$ in length, extends from Gaocun gauging station to Taochengpu cross-profile (35.6 km downstream of Sunkou gauging station). The spacing between the opposite main dykes in the reach is $1.2-8.9 \mathrm{~km}$, and two major tributaries, Tianranwenyanqu canal and the Jindihe River, converge into the left bank of the river. The river in this reach displays a transitional channel planform, varying from a wandering pattern gradually to a much less migrating meandering one. The lower reach of the LYR covers the final $322 \mathrm{~km}$, from Taochengpu cross-profile to Lijin gauging station located at the entrance of the river estuary. The longitudinal slope of this reach is about $0.01 \%$, and the channel at bankfull is relatively narrow and deep. Along most of this reach the channel at bankfull is relatively stable as it is restricted laterally by tight river training works on both sides of the bankfull channel (Fig. 3), only 0.4-5 km apart. A typical meandering channel in planform is 
taken by the river in this reach (Qian et al., 1987).

The cross-profiles of the LYR consist of a bankfull channel, a secondary floodplain, which extends from the edge of the bankfull channel to the secondary dykes that have been constructed by local farmers since the 1960s, and a main floodplain lying between the secondary and main dykes, as shown in Fig. 2. The secondary floodplain has been formed by sediment deposited during the migration of river channel and has a small transverse slope, with little vegetation cover and low flow resistance. The main floodplain of the LYR has been extensively populated at most places (around 180 million in total in the entire LYR), with extensive infrastructure (villages, roads) and large areas of farmland. These factors increase flow resistance to such a degree that the main floodplain has a smaller capacity for flow discharging than the secondary floodplain and the bankfull channel. Before the early 1960s, there were few river training works along the LYR. However, after the Sanmenxia Dam was constructed in 1960, there have been major changes in flow-sediment regime into the LYR, typically a marked decrease in sediment supply during 1960-1962 due to the water impoundment of the Sanmenxia Reservoir, resulting in extensive bank erosion in the LYR (Ma et al., 2012). This led to a rapid construction of river control projects along the LYR in the late 1960s, and river training works continue to be constructed until today, although by 2000 most of the works were practically completed. At the same time, in order to protect their homes and farmland, residents in the main floodplain have continually constructed small dykes on the two sides of the bankfull channel, forming a complex channel-floodplain system that constitutes two levels of floodplain along the LYR. In addition to the main dykes, the river training works and the secondary dykes have also played a role in controlling overbank floods to a considerable degree (Wu et al., 2005; Hu and Zhang, 2006; Hu et al., 2006; Zhang et al., 2016). 


\section{Data sources and research methods}

\subsection{Data sources}

There are seven gauging stations along the LYR, respectively at Huayunkou, Jiahetan, Gaocun, Sunkou, Aishan, Luokou and Lijin (see Fig. 1), most of which were set up by the Yellow River Water Conservancy Commission of China since 1950. Data used in this paper cover the period from 1950 to 2014, and include daily flow discharge, suspended sediment concentration and sediment discharge observed at the seven gauging stations. In addition, the dataset of the cross-profiles lying between the two opposite main dykes of the LYR as shown in Fig. 2 that have been measured is also deployed. There were ninety three cross-profiles that were measured in 1960 along the LYR at an around $8 \mathrm{~km}$ spacing. After 1999, the number increased to 329 , reducing the spacing to about $2.3 \mathrm{~km}$. The cross-profiles of the LYR have been measured twice a year, separately at the starting and ending times of flood season, or before July and after October each year. All of these data are collected from the hydrology yearbooks of the Yellow River drainage basin, which have been made available by the Yellow River Water Conservancy Commission of China.

\subsection{Research methods}

The amount of erosion or sediment deposition occurred in the LYR has been calculated using a sediment discharge method or a cross-profile method. The former examines the difference between sediment input at an upstream gauging station and sediment output at a downstream gauging station at the starting and ending times of each flood. The latter method takes four steps: (1) calculating the area differences in the bankfull channel and the main and secondary floodplains between two adjacent cross-profiles in terms of the corresponding measurements respectively at the starting and ending times of flood season (from July to October each year) (Fig. 4); (2) multiplying the means of the area differences by the distance between the two cross-profiles; (3) using a conversion factor of 1.65 to convert from $\mathrm{m}^{3}$ to 
metric tons; and (4) calculating the amount of erosion or deposition in the bankfull channel by subtracting the deposition in the main and secondary floodplains from the total erosion/deposition between two adjacent cross-profiles. Hence, the cross-profile method calculates the volume of erosion or deposition between two adjacent cross-profiles, $\Delta V$, in the form of:

$$
\Delta V=\left(\Delta S_{\mathrm{z}, 1}+\Delta S_{\mathrm{z}, 2}\right) L / 2
$$

where $\Delta S_{z, 1}$ is the area difference of cross-profile 1 during flood season, $\Delta S_{z, 2}$ is the area difference of cross-profile 2 adjacent to cross-profile 1 during flood season, and $L$ is the distance between the two adjacent cross-profiles.

Shen et al. (2006) suggested that there were systematic differences between the results of erosion and/or sedimentation distributed in the complex channel-floodplain system of the LYR calculated using the cross-profile and the sediment discharge methods. They showed that the sediment discharge method produced larger sedimentation values than the cross-profile method in the reach above Huayuankou gauging station, close values in the reach from Huayuankou to Gaocun gauging stations, smaller values in the reach from Gaocun to Aishan gauging stations, and close values in the final reach from Aishan to Lijin gauging stations. The cross-profile method has been regarded as a better option because it does not yield accumulated error. Nevertheless, the cross-profiles of the LYR have been measured only twice a year, separately in the starting and ending times of flood season, or before July and after October each year. Hence, the cross-profile method yields the spatial distribution of erosion/deposition in the channel-floodplain system for all floods occurred in the entire flood season other than for each individual flood. In contrast, the sediment discharge method has an advantage of yielding the total amount of sedimentation/erosion for each individual flood and yet cannot yield the distribution of deposition/erosion in all parts of the entire cross-profile. As a result, the sediment discharge method has been used to calculate the total amount of 
erosion/deposition for each flood and the results were then adjusted using a coefficient of modification for sediment discharge $(K)$. As detailed by Li and Long (1994), the coefficient $K$ is defined as the ratio of $Q_{\text {smep }}$ to $Q_{\text {sm }}$, in which $Q_{\text {smep }}$ is the total sediment discharge calculated by the "Modified Einstein Procedure" and $Q_{\mathrm{sm}}$ is the measured sediment discharge. Because the coefficient $K$ is correlated with the sediment concentration of flow, it was whitened by a whitening function and the whitened $\mathrm{K}$ value was multiplied by $Q_{\text {sm }}$ to obtain the modified sediment discharge $Q_{\text {smod }}$.

In line with the continual development of empirical methods, Liu et al. (1986) developed a computational method to determine the distribution of sedimentation for each reach between two adjacent cross-profiles of the LYR during large floods, by incorporating the sediment carrying capacity formula proposed by Zhang (1998) into the Muskingum hydrological model. With this method and using measured cross-profile data and sedimentation survey reports for calibration, they calculated the distribution of erosion/deposition in the bankfull channel and on the main and secondary floodplains along the entire LYR for all large floods observed since 1950. Their results have been regarded as the most reliable so far and so we adopt them in this study.

Previous studies on the fluvial process of the LYR have shown in many occasions that the sediment transport coefficient $\mathrm{C} / \mathrm{Q}$, or the ratio of sediment concentration of flow to flow discharge, is a good indicator of the regime of water and sediment transported (Qian and Zhou, 1965; Xu, 2004; Hu et al., 2006). Hence, this coefficient is used in this study as a key parameter to understand the erosion and sedimentation dynamics of large floods in the complex channel-floodplain system of the LYR.

Sediment transport in the LYR occurs mainly in flood periods and the distribution of sedimentation over the floodplains and the bankfull channel differs from one flood to another. To evaluate the differences in the distribution, overbank floods in the LYR have been divided 
into two types, large and small, using two different methods. The first method is based on the extent of water inundation (Yao et al., 2007). According to this method, large overbank floods are those in which water can flow over the top of the secondary dykes and reaches up to the main dykes, while small overbank floods reach only as far as the secondary dykes (Fig. 2).

The second method is based on the ratio of peak discharge $Q_{\max }$ to bankfull discharge $Q_{\mathrm{p}}$ (Zhang et al., 2006). In this method, large overbank floods are defined as those during which peak discharge $\left(Q_{\max }\right)$ is larger than 1.5 times bankfull discharge $\left(Q_{p}\right)$, or $Q_{\max } / Q_{p}>1.5$, while small overbank floods are those during which peak discharge is 1.0-1.5 times bankfull discharge, $1.0<Q_{\max } / Q_{p} \leq 1.5$. The two methods have different advantages and disadvantages. The first has a difficulty in accurately reflecting the inundating boundaries of overbank floods, while the second method can filter out some large overbank floods from a flood series. To overcome the disadvantages of the two methods, we adopt an integrated classification method in this study. At the first stage, all overbank floods are classified into large and small ones using the overbank coefficient $Q_{\max } / Q_{p}$. Then, the amounts of erosion/deposition in the bankfull channel and on the main and secondary floodplains are calculated separately for large and small overbank floods using the measured cross-profile data and sedimentation survey reports. Finally, small and large overbank floods are re-classified on the basis of actual sedimentation areas.

\section{Changes in runoff, sediment load and floods}

4.1 Changes in runoff and sediment load

The runoff of most Chinese rivers has been decreasing in recent years and the LYR is no exception (Xu, 2004; Ma et al., 2012; Zhang et al., 2016). Fig. 5 presents the annual runoff and annual suspended sediment load observed during 1950 to 2014 at Huayuankou gauging station, located in the upper LYR and about $129.6 \mathrm{~km}$ downstream of the Xiaolangdi Dam 
(Fig. 1). The data show a declining trend in both runoff and sediment load since 1965, with the decline in the latter especially marked after 2000. The average annual runoff at Huayuankou station during $1950-2014$ was $372 \times 10^{8} \mathrm{~m}^{3}$, and the average annual sediment load was $8.4 \times 10^{8}$ tons, while since 2000 the average annual runoff declined to $255 \times 10^{8} \mathrm{~m}^{3}$, and the average sediment load was only $0.9 \times 10^{8}$ tons. The average annual runoff after 2000 was $69 \%$ of the long term average (1950-2014), and the average annual sediment load only 11\%. With the Xiaolangdi Reservoir coming into full operation in 2002, a Water and Sediment Regulation Scheme (WSRS) has been implemented since then. As detailed by Ma et al. (2012) and Zhou et al. (2015), this scheme takes the advantages of the large volume of the Xiaolangdi Reservoir and the location of the dam at the entrance of the LYR, and, in a joint operation with the upstream Longyangxia, Liujiaxia, Sanmenxia and Wanjiazhai Reservoirs, releases water and sediment load into the LYR under a considerable degree of control. The operational modes of the WSRS scheme are mainly: (1) supplying sufficient water to the LYR and the estuary of the Yellow River so as to make the regional ecosystems sustainable; and (2) storing clear water and yet discharging sediment-laded flow, typically large floods so as to prevent the Xiaolangdi Reservoir from losing volume at a fast speed.

\subsection{Types of overbank floods}

Different overbank floods have different capacities to shape the channel and the floodplains of the LYR. Although large overbank floods cause serious problems to floodplain users and flood-protecting agents, they mostly result in erosion in the channel and deposition on the floodplains, which leads to a net increase in the discharging capacity of the channel. Indeed, there is a saying of "large floods often form good channels" in China (Qian et al., 1987). For example, the LYR overbank flood occurred in July 1958 resulted in $10.7 \times 10^{8}$ tons of floodplain deposition and $8.6 \times 10^{8}$ ton of erosion in the bankfull channel (Qian and Zhou, 1965). Therefore, overbank floods have played a very important role in shaping the 
bankfull channel and in distributing sediment deposition across the floodplains in the LYR.

Among all floods occurred at Huayuankou station since 1950, 44 of them have overbank coefficients, or $Q_{\max } / Q_{p}$, larger than 1.0 (Fig. 6), including 16 floods with $Q_{\max } / Q_{\mathrm{p}}>1.5$ and 28 floods with $1.0<Q_{\max } / Q_{\mathrm{p}} \leq 1.5$. However, it is necessary to consider the effect of flood duration as it can impact on the inundating extent of floods. When flooding duration is short, overbank floods with overbank coefficients greater than 1.5 can rarely reach the main dykes, resulting in little deposition on the main floodplain. These floods are thus excluded from the category of large overbank floods and re-classed into the category of small overbank floods. Hence, large overbank floods are defined in this study as those during which sediment deposition occurred on both of the main and secondary floodplains, while small overbank floods refer to those during which sediment deposition occurred predominantly on the secondary floodplain. With this definition, we classified all overbank floods observed at Huayuankou station since 1950 into 12 large overbank floods (Table 1) and 31 small overbank floods (Table 2).

It can be noticed in Table 1 that nearly a half of the large overbank floods occurred at Huayuankou station before the Sanmenxia Reservoir was constructed in 1960. The Sanmenxia Reservoir initially had a capacity of controlling $89 \%$ of the runoff and $98 \%$ of sediment input from the upstream (Pan et al., 2006). When water and sediment were impounded in the Sanmenxia Reservoir during 1960-1964, marked erosion occurred in the channel of the LYR, often accompanied by bank collapses. To prevent the banks of the channel from collapsing, a lot of river training works have been put in place since 1960 . During the period 1965-1973, the operating mode of the Sanmenxia Reservoir was changed to flood retardation and sediment release from the reservoir. This led to considerable sediment deposition in the channel of the LYR and a rapid decrease in the discharging capacity of the channel over the period. During 1974-1985, large overbank floods occurred less frequently in the LYR, only five in total. Since 1986, only one large overbank flood 
occurred. This is partly due to the construction of the Longyangxia Reservoir in the upper Yellow River in 1986, the largest reservoir in the Yellow River drainage basin, which reduces the peak discharges of floods into the LYR considerably and also makes overbank floods occur less frequently in the LYR (Ma et al., 2012).

During 16-21 June 1958, the LYR experienced the largest flood in record with a peak flow discharge of 22,300 $\mathrm{m}^{3} \mathrm{~s}^{-1}$ observed at Huayuankou gauging station. Since then the flow discharge of $22,300 \mathrm{~m}^{3} \mathrm{~s}^{-1}$ has been treated as the standard of the LYR for flood prevention. The flood was a typical rainfall event, with heavy rainfall falling over the drainage area from the Sanmenxia Reservoir to Huayuankou station, covering the drainage basins of the Yiluohe River and Qinhe River tributaries. During the flood, the highest water level at Huayuankou station reached $93.82 \mathrm{~m}, 0.09 \mathrm{~m}$ higher than the previously recorded highest in 1933, and the water reached the main dykes almost throughout the entire LYR with a depth of about 4-6 m, lasting for 35-80 hours. This large overbank flood resulted in sedimentation of $10.7 \times 10^{8}$ tons on the floodplain, which was twice of the incoming sediment load, while the bankfull channel was subject to erosion of $8.6 \times 10^{8}$ tons at the same time.

The second largest flood on record at Huayuankou station occurred in August 1982, with a peak discharge of $15,300 \mathrm{~m}^{3} \mathrm{~s}^{-1}$. The total volume of water in seven days reached $5.02 \times 10^{8}$ $\mathrm{m}^{3}$, and the flood duration for flow discharges of larger than $10,000 \mathrm{~m}^{3} \mathrm{~s}^{-1}$ lasted for 52 hours. Water reached the main dykes almost throughout the entire LYR, with a depth of about 2-4 m, and the peak discharge was 2.55 times the bankfull discharge. However, this flood resulted in only a small amount of sedimentation across the entire cross-profiles of the LYR due to its relatively low suspended sediment concentration (SSC) of $32.6 \mathrm{~kg} \mathrm{~m}^{-3}$, with a deposition of $2.56 \times 10^{8}$ tons on the floodplain and erosion of $2.27 \times 10^{8}$ tons from the channel below bankfull.

The flood occurred at Huayuankou station in August 1977 was exceptional. The 
significant characteristic of this flood was its high sediment concentration of $302.2 \mathrm{~kg} \mathrm{~m}^{-3}$, 9.3 times that of the 1958 flood. During this hyper-concentrated flood, peak discharge reached $10,800 \mathrm{~m}^{3} \mathrm{~s}^{-1}$, and the ratio of peak discharge to bankfull discharge was 1.74 . Due to the high sediment concentration, the whole LYR was subject to extreme deposition, with 5.02 $\times 10^{8}$ tons of deposition in the bankfull channel and $6.44 \times 10^{8}$ tons of deposition on the main and secondary floodplains. As a result, the bankfull channel shrank considerably, with the bankfull channel width decreasing to $500 \mathrm{~m}$, only one-sixth of the counterpart before the flood.

There were 31 small overbank floods observed at Huayuankou station since 1950. This type of floods occurred frequently before 1960, at least once a year, but only occurred once a year on average between 1960 and 1964. During the periods 1965-1973 and 1986-1999, small overbank floods occurred once every 2.5 years and 2.0 years, respectively. The decline in the frequency of small overbank floods since 1960 is due to climatic change and intensive human activities (Zhou et al., 2015).

There are four floods that are classified as small overbank floods in this study even though the ratios of their peak discharges to bankfull discharges are larger than 1.5, occurring respectively in 1959, 1973, 1992 and 1994 (Table 2). During these floods, overbank flow did not reach the main dykes, and there was almost no deposition on the main floodplain. Their peak discharges were relatively small, between 5,890 and 9,480 $\mathrm{m}^{3} \mathrm{~s}^{-1}$, and the concentrations of suspended sediment in these floods took moderate to high values $\left(21.5-348 \mathrm{~kg} \mathrm{~m}^{-3}\right)$. Although small in quantity varying in the range of $0.33-2.56 \times 10^{8}$ tons, sediment deposition occurred during these floods mainly on the secondary floodplain near the bankfull channel, which exacerbated the problem of "the secondary perched river" along the already perched LYR (Hu and Zhang, 2006). 


\section{Sedimentation distribution during overbank floods}

5.1 Erosion and deposition distribution during large overbank floods

The erosional and/or depositional distributions in the complex channel-floodplain system of the LYR during 12 large overbank floods occurred since 1950 are presented in Table 3 and shown in Fig. 7. It can be noticed from Fig. 7(a) that when the sediment transport coefficient $C / Q$ is larger than $0.034 \mathrm{kgsm}^{-6}$, deposition takes place not only on the main and secondary floodplains but also in the bankfull channel. In contrast, when the $C / Q$ is smaller than $0.034 \mathrm{kgsm}^{-6}$, deposition occurs only on the main and secondary floodplains, while the bankfull channel is subject to significant erosion. A typical example is the overbank flood occurred in 1958, which had the largest peak discharge of $22,300 \mathrm{~m}^{3} \mathrm{~s}^{-1}$ at Huayuankou station since 1950, and yet with a sediment transport coefficient of $0.01 \mathrm{kgsm}^{-6}$, it resulted in erosion of $8.6 \times 10^{8}$ tons off from the bankfull channel, while at the same time deposited $10.69 \times 10^{8}$ tons of sediment on the main and secondary floodplains across the entire LYR. In contrast, the 1975 flood had a relatively small peak flow discharge of $7,580 \mathrm{~m}^{3} \mathrm{~s}^{-1}$ at Huayuankou station, and yet with a sediment transport coefficient of $0.006 \mathrm{kgsm}^{-6}$, it resulted in deposition of $3.39 \times 10^{8}$ tons on the main and secondary floodplains and erosion of $2.68 \times$ $10^{8}$ tons off the bankfull channel over the entire LYR.

During these large overbank floods, most of erosion in the bankfull channel and deposition on the floodplains (around $70 \%$ of the total) took place in the upper and middle reaches of the LYR, with only a limited amount occurring in the reach downstream of Aishan gauging station. Clearly, because large overbank floods have a function of "floodplain deposition and bankfull channel erosion", they can help to shape a relatively narrow and deep bankfull channel so as to increase the capacity of discharging floods along the LYR. This function of large overbank floods offers important suggestions for flood control in the LYR. That is, large overbank floods with a sediment transport coefficient $\mathrm{C} / Q$ of smaller than 0.034 
should be less controlled or not controlled at all when they enter the LYR. However, large overbank floods with a high sediment transport coefficient $(C / Q>0.034)$ should be controlled because they can lead to considerable deposition also in the bankfull channel along the LYR, which can accelerate the development of a higher perched channel within the LYR. Liu et al. (2009) also made similar suggestions in terms of their detailed investigation of the features of high-sediment floods occurred in the LYR.

Among 12 large overbank floods, 10 of them have sediment transport coefficients of smaller than $0.034 \mathrm{kgsm}^{-6}$ and Fig. 7(b) shows the relationship between erosion in the bankfull channel and deposition on the main and secondary floodplains. It can be seen that, the higher the amount of deposition on the floodplains, the larger the amount of erosion in the bankfull channel. The erosion in the bankfull channel is 0.46-0.99 times the floodplain deposition, about 0.74 times on average. Because the main and secondary floodplains have a lower sediment transport capacity, sediment entering the floodplains is mostly deposited. Therefore, the amount of floodplain deposition during large overbank floods can be calculated by the volume of water entering the floodplains and the sediment concentration of flow over the floodplains. Figs.7(c)(d)(e)(f) presents the relationships between the amount of floodplain deposition and key important factors, particularly $C$ (average sediment concentration of overbank flow during a flood), $W_{0}$ (volume of water entering the floodplain), and $Q_{\text {max }} / Q_{p}$ (overbank flow coefficient defined as the ratio of peak flow discharge to bankfull discharge). It can be seen that the overbank flow coefficient $Q_{\max } / Q_{p}$ is one of the important factors that determine the amount of floodplain deposition; with an increase in $Q_{\max } / Q_{p}$, the amount of floodplain deposition also increases. Other factors, especially $W_{0}$ and $C$, also influence floodplain deposition to a degree. By integrating the effects of the three factors with a regression analysis method, a formula for calculating the amount of floodplain deposition during large overbank floods in the LYR can be obtained: 


$$
C_{\mathrm{sn}}=W_{0}{ }^{0.25} C^{0.4}\left(Q_{\max } / Q_{\mathrm{p}}\right)^{1.13} \quad\left(r^{2}=0.85\right)
$$

where $C_{\mathrm{sn}}$ is the amount of floodplain deposition $\left(10^{8}\right.$ tons $), C$ is the average sediment concentration of flow over the main and secondary floodplains $\left(\mathrm{kg} \mathrm{m}^{-3}\right), W_{0}$ is the volume of water entering into the main and secondary floodplains $\left(10^{8} \mathrm{~m}^{3}\right), Q_{\max }$ is the peak flow discharge $\left(\mathrm{m}^{3} \mathrm{~s}^{-1}\right), Q_{\mathrm{p}}$ is the bankfull flow discharge $\left(\mathrm{m}^{3} \mathrm{~s}^{-1}\right)$, and $r^{2}$ is the correlation coefficient.

The amount of erosion in the bankfull channel during large overbank floods is mainly related to the volume of water and sediment load transported. In general, as water volume increases, the erosion in the bankfull channel also increases and the larger the sediment load, the smaller the erosion for the same volume of water supplied. This explains why the erosion in the bankfull channel is more effective during large overbank floods than non-overbank floods. Because sediment load carried by large overbank flow is mainly deposited on the main and secondary floodplains, the clear water resulted from the deposition returns to the bankfull channel downstream owing to the effect of river training works and the main and secondary dykes constructed along the LYR and consequently leads to a significant increase in the erosion in the bankfull channel. Thus, sediment deposition on the floodplains also has a significant influence on the erosion in the bankfull channel. Taking $W_{0}^{0.25} C^{0.4}\left(Q_{\max } / Q_{\mathrm{p}}\right)^{1.13}$ as an integrated factor in terms of Eq. (2), Fig. 7(f) shows the relationship between the erosion in the bankfull channel and the integrated factor. It can be noticed clearly from Fig. 7(f) that, the higher the integrated factor, the more erosion in the bankfull channel. In addition, the volume of water and the amount of sediment in flood season also influence the erosion in the bankfull channel to a degree. By integrating the effects of these factors together, the following formula can be obtained:

$$
C_{\mathrm{sp}}=-0.054-0.003 W_{0}+0.248 W_{\mathrm{s}}-0.103 W_{0}^{0.25} C^{0.4}\left(Q_{\max } / Q_{\mathrm{p}}\right)^{1.13} \quad\left(r^{2}=0.81\right)
$$

where $C_{\mathrm{sp}}$ is the amount of erosion in the bankfull channel $\left(10^{8}\right.$ tons $), W$ is the water volume 
in the concerned flood period $\left(10^{8} \mathrm{~m}^{3}\right)$, and $\mathrm{Ws}$ is the sediment load in the concerned flood period $\left(10^{8}\right.$ tons $)$.

5.2 Erosion and deposition distribution during small overbank floods

Each cross-profile of the LYR has been measured twice each year, respectively in the starting and ending times of a flood season. When the cross-profile method is applied to determine the amount of floodplain sedimentation and if more than one overbank floods occurred in the flood season, the effects of these floods cannot be distinguished separately because the amount of sediment deposition is the combined result of all the floods occurred in the flood reason. For 11 small overbank floods available (the two floods occurred in 1994 are combined together), Table 4 shows the calculated erosion and deposition distribution on the main and secondary floodplains. It can be noticed that most deposition is concentrated on the secondary floodplain, with little deposition on the main floodplain. With the data presented in Table 4, the relationship between the bankfull channel erosion, floodplain deposition, and the sediment transport coefficient (C/Q), is shown in Fig 8. When the sediment transport coefficient is below 0.028 , erosion occurs in the bankfull channel, but when the sediment transport coefficient is above 0.028 , the bankfull channel and the secondary floodplain are both depositional (Fig. 8(a)). Noticeably in Fig 8(b), the larger the sediment transport coefficient (C/Q), the smaller the amount of erosion in the bankfull channel and a log function appears suitable to describe the relationship. In addition, water volume appears another key factor because the erosion in the bankfull channel increases generally with an increase in water volume. By integrating the effects of the two factors, the best-fit equation for the quantity of erosion occurred in the bankfull channel can be determined by:

$$
C_{\mathrm{sp}}=4.61+1.07 \ln (C / Q)-0.003 W \quad\left(r^{2}=0.70\right)
$$


where $C_{\mathrm{sp}}$ is the amount of erosion in the bankfull channel $\left(10^{8}\right.$ tons $)$ and $\mathrm{C} / \mathrm{Q}$ is the sediment transport coefficient $\left(\mathrm{kgsm}^{-6}\right)$.

In comparison with large overbank floods, the extent of floodplain sedimentation during small overbank floods is much smaller because almost no or much less water and sediment entered the main floodplain during small overbank floods. Importantly, the sediment concentration of flow appears a key factor affecting floodplain sedimentation during small overbank floods and the best fit equation for the relationship is found to take a form of:

$$
C_{\mathrm{sn}}=0.0071 C+0.1564 \quad\left(r^{2}=0.44\right)
$$

where $C_{\mathrm{sn}}$ is the amount of floodplain deposition ( $10^{8}$ tons).

Large and small overbank floods have different sedimentation patterns. It can be seen from Fig. 9 that the percentage of deposition on the main floodplain is about $42 \%$ during large overbank floods, but only $12 \%$ during small overbank floods. The distribution of sedimentation is also different, with $50 \%$ of the sedimentation taking place between the main and secondary dykes during large overbank floods, while most of the sedimentation occurs between the edges of the bankfull channel and the secondary dykes, or the secondary floodplain, during small overbank floods.

5.3 Difference in sedimentation distribution between overbank and non-overbank floods

During the period 1951 to 2004,171 non-overbank floods occurred in the LYR. To evaluate the efficiency of this type of floods on sedimentation, the quantity of erosion/deposition per unit flow discharge is used in this study. It can be seen in Fig. 10 that the efficiency of this type of floods on sedimentation is related closely to the sediment concentration of flow. With an increase in the sediment concentration of flow, more sedimentation takes place. This is because a higher sediment concentration means that flow carries more sediment and so can cause more sedimentation. Interestingly, such a relationship appears suitable also for evaluating the efficiency of small overbank floods on sedimentation 
not only in the bankfull channel but also on the floodplains, although some differences exist among the three best-fitted linear relationships as shown in Fig. 10. The efficiency of large overbank floods on sedimentation in the bankfull channel and on the floodplains, however, does not have such a close relationship. This is because the efficiency of large overbanks floods on sedimentation is determined by many factors, as illustrated clearly in Eqs. (2) and (3).

5.4 Distribution of floodplain sedimentation in different reaches

The distribution of floodplain deposition during large overbank floods in the different reaches of the LYR is shown in Fig. 11. The majority of floodplain deposition is concentrated on the reach upstream of Sunkou station, accounting for $52-100 \%$ of the deposition in the entire LYR (Fig. 11(a)). Deposition on the secondary floodplain also occurred to a considerable degree in the reach upstream of Sunkou station, accounting for $58 \%$ of the total floodplain deposition. The bankfull channel is subject to erosion during most large overbank floods, with the highest erosion concentrated in the reaches of hyk-jht (Huayuankou to Jiahetan stations), jht-gc (Jiahetan to Gaocu stations) and gc-sk (Gaocun to Sunkou station), accounting for $57 \%, 61 \%, 92 \%, 225 \%$ (some sedimentation), $1170 \%$ (some sedimentation ) and $57 \%$ of the total erosion respectively in 1975, 1976, 1977, 1982, 1988 and 1996 (Fig. 11(b)).

Floodplain deposition along the LYR during small overbank floods is also concentrated in the reaches upstream of Sunkou station as shown in Fig. 12, accounting for $94 \%$ of the total floodplain deposition. The secondary floodplain deposition took $78 \%$ of the total floodplain deposition, and so only a small proportion was deposited on the main floodplain (Fig. 12(a)). The bankfull channel is subject to erosion only during some small overbank floods, occurring mostly in the reaches upstream of Sunkou station (Fig. 12(b)). The main reason for the floodplain deposition occurring predominantly in the reaches upstream of 
Sunkou station is that the total width of the main and secondary floodplains in these reaches is very large, with a maximum spacing of $15.4 \mathrm{~km}$ and an average spacing of $6 \mathrm{~km}$ between the main dykes on the opposite sides (Fig. 13). In contrast, the average inter-dyke distance in the reaches downstream of Sunkou station is only $2.1 \mathrm{~km}$, with a maximum of $2.7 \mathrm{~km}$. The spacing between the secondary dykes in the entire LYR follows the same pattern, with an average of $4.3 \mathrm{~km}$ in the reaches upstream of Sunkou station (Fig. 13) and a maximum of 7.3 $\mathrm{km}$. In contrast, the average spacing in the reaches downstream of Sunkou station is only 0.9 $\mathrm{km}$, and a maximum of $3.9 \mathrm{~km}$. Hence, the reaches downstream of Sunkou station have a very limited room for floodplain deposition to take place.

In addition, the cross-sections of the bankfull channel are very shallow in the reaches upstream of Gaocun station, with ratios of channel width to depth being especially high in the wandering reach. At these shallow cross-sections, overbank flow takes place much easily, causing erosion in the bankfull channel and deposition on the floodplains, along with a significant flood retention. This brings about a significant reduction in both peak discharge of floods and sediment load in the reaches downstream of Sunkou station, limiting the potential for floodplain deposition.

5.5 Long-term sedimentation during overbank floods

During the 1950s both runoff and sediment input to the LYR were very large in quantity, with an average annual runoff of $467.5 \times 10^{8} \mathrm{~m}^{3}$ and an average annual sediment load of $16.98 \times 10^{8}$ tons. The highest annual runoff and annual sediment load occurred in 1958 , of $643.8 \times 10^{8} \mathrm{~m}^{3}$ and $31.2 \times 10^{8}$ tons, respectively. During 1950 to 1960 , six large overbank floods occurred in the LYR, among which most of the peak flow discharges exceeded $10,000 \mathrm{~m}^{3} \mathrm{~s}^{-1}$, with the largest of $22,300 \mathrm{~m}^{3} \mathrm{~s}^{-1}$ occurred in 1958 . The secondary dykes and river training works had not been built up then, and hence much more floodwater entered the main floodplain and a large amount of sediment deposited there, while erosion 
occurred in the bankfull channel. The average annual sedimentation during July 1950 to June 1960 is presented in Table 5, which shows that $27.9 \times 10^{8} \mathrm{~m}^{3}$ of sediment was deposited in the entire LYR over the period, with the bankfull channel taking $8 \times 10^{8} \mathrm{~m}^{3}$ (29\% of the total) and the floodplain $19.9 \times 10^{8} \mathrm{~m}^{3}(71 \%)$. The sedimentation in the bankfull channel is reflected in the change of water levels at a specific same flow discharge. Fig. 14 is plotted to show the difference in the pre-flood water levels under the same flow discharge of 3,000 $\mathrm{m}^{3} \mathrm{~s}^{-1}$, with the water level in July 1950 as a reference level. It can be noticed that the reach upstream of Aishan gauging station has the largest water-level difference of up to $1.3 \mathrm{~m}$ between 1950 and 1960, while the difference downstream of Aishan station takes a value less than $0.5 \mathrm{~m}$. This means that the quantity of sedimentation in the reach downstream of Aishan station is less significant, consistently with the observations shown in Table 5.

The bankfull channel was erosional during 1960-1964 because the Sanmenxia Reservoir stored all sediment entering the reservoir. It can be seen from Fig. 14 that the water levels at all station upstream of Linjin station all dropped during 1960 to 1964 . The distribution of sedimentation in the different reaches of the LYR during 1965-1999 is shown in Table 6. In this period, $501 \times 10^{8} \mathrm{~m}^{3}$ of sediment was deposited in the LYR, with the bankfull channel and the main floodplain taking $353.4 \times 10^{8} \mathrm{~m}^{3}(71 \%)$, and $91.7 \times 10^{8} \mathrm{~m}^{3}(18 \%)$, respectively.

During 1965 to 1973 and 1986 to 1999 , the bankfull channel was aggrading and $237.1 \times 10^{8}$ $\mathrm{m}^{3}$ of sediment was deposited in the LYR, with the main floodplain taking $11.2 \times 10^{8} \mathrm{~m}^{3}$, only $5 \%$ of the total, and the secondary floodplain and the bankfull channel taking the most. From 1986 to $1999,223.8 \times 10^{8} \mathrm{~m}^{3}$ of sediment was deposited in the LYR, with the main floodplain taking only $15.8 \times 10^{8} \mathrm{~m}^{3}$, accounting for $7 \%$ of the total. Most of the deposition occurred in the bankfull channel, accounting for $85 \%$ of the total. In the intervening period from 1974 to 1985 , however, erosion of $44.5 \times 10^{8} \mathrm{~m}^{3}$ occurred in the bankfull channel, while 
the secondary and main floodplains received deposition of $19.9 \times 10^{8} \mathrm{~m}^{3}$ and $61.3 \times 10^{8} \mathrm{~m}^{3}$, respectively.

Table 7 shows sedimentation rates in the different reaches of the LYR during 1965-1999. In the reach from Huayuankou to Gaocun stations the rate was $0.073 \mathrm{my}^{-1}$ in the bankfull channel, $0.034 \mathrm{my}^{-1}$ on the secondary floodplain, and $0.013 \mathrm{myr}^{-1}$ on the main floodplain. In the reach upstream of Huayuankou station, the elevation of the main floodplain has been relatively high, so little water can enter, resulting in a sedimentation rate of only $0.005 \mathrm{my}^{-1}$. Downstream of Gaocun station the main floodplain is relatively lower and much narrower, with a sedimentation rate of $0.013-0.014 \mathrm{my}^{-1}$. Generally, in the entire LYR, the secondary floodplain has a higher sedimentation rate than the main floodplain.

\section{Conclusions}

Since the 1950s the Lower Yellow River (LYR) has experienced continual reinforcement and construction in the main and secondary dykes and river training works, along with a significant change in the type, frequency and magnitude of floods. To understand how the resulted complex channel-floodplain system behaves in response to the occurrence of large floods, this study presented a detailed investigation of the relationship between the tempo-spatial distribution of sedimentation/erosion and the types of floods and uncovered the following features of the complex channel-floodplain interaction in the LYR:

(1) During large overbank floods, sediment deposition occurs on the main and secondary floodplains while erosion takes place in the bankfull channel when the sediment transport coefficient (ratio of sediment concentration to flow discharge) is smaller than 0.034 . The amount of sediment deposition on the main and secondary floodplains is related closely 
to the volume of water entering the floodplains, overbank coefficient (ratio of peak discharge to bankfull discharge), and sediment concentration of overbank flow. In contrast, the amount of erosion in the bankfull channel is related closely to water volume and sediment load in flood season, as well as the amount of sediment deposited on the main and secondary floodplains. When the sediment transport coefficient is larger than 0.034 , sediment deposition occurs not only on the main and secondary floodplains but also in the bankfull channel. However, large overbank floods with sediment transport coefficients larger than 0.034 can result in considerable deposition in the bankfull channel in the entire LYR.

(2) During small overbank floods, erosion takes place in the bankfull channel while sediment deposition occurs on the secondary floodplain when the sediment transport coefficient is smaller than 0.028 . The amount of erosion in the bankfull channel is related closely to the sediment transport coefficient and water volume in flood season, while the amount of sediment deposited on the secondary floodplain is closely related only to the sediment concentration of flow. When the sediment transport coefficient is larger than 0.028 , sediment deposition occurs in the bankfull channel as well as on the secondary floodplain.

(3) Sediment deposition on the main floodplain is concentrated mostly in the upper reach of the LYR (upstream of Sunkou station), with a limited amount of deposition occurring in the downstream reach. This is due to a dramatic downstream reduction in the width of the main and secondary floodplains and the associated change in river channel planform. In the reach upstream of Sunkou station, floodplains are broad and flow runs in an unstable wide and shallow channel that exhibits a wandering pattern in planform, offering a large space for flood retention and sediment deposition. Downstream of Sunkou station, the inter-dykes distance becomes much smaller and flow runs in a meandering and deeper channel, providing less space for sediment deposition on the floodplains.

Since the Xiaolangdi Reservoir took full operation in 2002, both runoff and sediment 
load entering the LYR have been regulated to a considerable degree and overbank floods rarely occur, especially very large overbank floods. The results of this study, however, have shown that it ought to release some large overbank floods from the reservoir because these floods can cause significant erosion in the bankfull channel of the LYR while a large amount of sediment are deposited on the main and secondary floodplains. These overbank floods are also beneficial to the conservation of the wetland ecosystems and the sustainable use of agricultural land developed in the floodplains of the LYR.

\section{Acknowledgements}

This study was carried out under the financial support of the National Natural Science Foundation of China $(41330751,51179181)$ and the National Key R\&D Program of China (2016YFC0402407). The authors would like to thank the Yellow River Water Conservancy Commission of China for permission to access the observed hydrological data. The editor and two anonymous reviewers are also thanked for their valuable comments, which have significantly improved the quality of this paper.

\section{References}

Aalto R, Lauer JW, Dietrich WE. 2008. Spatial and temporal dynamics of sediment accumulation and exchange along Strickland River floodplains (Papua New Guinea) over decadal-to-century timescales. Journal of Geophysical Research 113:1-22

Aalto R, Maurice-Bourgoin L, Dunne T, Montgomery DR, Nittrouer CA, Guyot JL. 2003. Episodic sediment accumulation on Amazonian floodplains influenced by El N.no/Southern Oscillation. Nature 425: 493-497.

Adams PN, Slingerland RL, Smith ND. 2004. Variations in natural levee morphology in anastomosed channel floodplain complexes. Geomorphology 61: 127-142.

Alexander CS, Prior JC. 1971. Holocene sedimentation rates in overbank deposits in the Black Bottom of the Lower Ohio River, southern Illinois. American Journal of Science 270: $361-372$.

Allison M.A., Kuehl S.A., Martin, T.C, Hassan, A. 1998. Importance of floodplain sedimentation for river sediment budgets and terrigenous input to the oceans: Insights from the Brahmaputra-Jamuna River. Geology 26:175-178

Belyaev VR, Golosov VN, Markelov MV, Evrard O, Ivanova NN, Paramonova TA, 
Shamshurina EN. 2013. Using Chernobyl-derived 137Cs to document recent sediment deposition rates on the River Plava floodplain (Central European Russia). Hydrological Processes 27: 807-821.

Benedetti MM. 2003. Controls on overbank deposition in the Upper Mississippi River. Geomorphology 56: 271-290.

Brown AG. 1983. An analysis of overbank deposits of a flood deposit at Blandford-Forum, Dorest, England. Revue de Geomorphology 32(2): 95-99.

Chen J, Zhou W, Chen Q. 2012. Channel re-establishment of the Lower Yellow River in ten years operation of Xiaolangdi Reservoir. Journal of Hydrodynamics 24(6): 127-135.

Chu Z. 2014. The dramatic changes and anthropogenic causes of erosion and deposition in the lower Yellow (Huanghe) River since 1952. Geomorphology 216: 171-179.

Citterio A, Piégay H. 2009. Overbank sedimentation rates in former channel lakes: characterization and control factors. Sedimentology 56: 461-482.

Constantine JA, Dunne T, Piegay H. 2010. Controls on the alluviation of oxbow lakes by bed-material load along the Sacramento River, California. Sedimentology 57:389-407

Constantine JA, Dunne T, Ahmed J, Legleiter C, Lazarus ED. 2014. Sediment supply as a driver of river meandering and floodplain evolution. Nature Geoscience 7: 899-903.

Day G, Dietrich WE, Rowland JC, Marshall A. 2008. The depositional web on the floodplain of the Fly River, Papua New Guinea. Journal of Geophysical Research 113:1-19.

Dieras PL, Constantine JA, Hales TC, Piégay H, Riquier J. 2013. The role of oxbow lakes in the off-channel storage of bed material along the Ain River, France. Geomorphology.

Dunne, T, Mertes, LAK, Meade, RH, Richey, JE, Forsberg, BR. 1998. Exchanges of sediment between the floodplain and channel of the Amazon River in Brazil. Geol. Soc. Am. Bull 110:450-467.

Farrell KM. 2001. Geomorphology, facies architecture, and high resolution, non-marine sequence stratigraphy in avulsion deposits, Cumberland Marshes, Saskatchewan. Sedimentary Geology 139: 93-150.

Gomez B, Mertes L, Philips JD, Magilligan FJ, James LA. 1995. Sediment characteristics of an extreme flood: 1993 Upper Mississippi River valley. Geology 23: 963-966.

Goodbred SL Jr, Kuehl SA. 1998. Floodplain processes in the Bengal Basin and the storage of Ganges-Brahmaputra river sediment: an accretion study using Cs-137 and Pb-210 geochronology. Sediment. Geology 121: 239-258

Harrison LR, Dunne T, Fisher GB. 2015. Hydraulic and geomorphic processes in an overbank flood along a meandering, gravel-bed river: implications for chute formation. Earth Surface Processes and Landforms 40: 1239-1253.

He Q, Walling DE. 1996. Use of fallout Pb-210 measurements to investigate longer-term rates and patterns of overbank sediment deposition on the floodplains of lowland rivers. Earth Surface Processes and Landforms 21:141-154

Hou Z, Li Y, Wang W. 2010. Sedimentation and interrelationship in the main channel and floodplain of the lower Yellow River. Yellow River 32(10): 63-67. (in Chinese)

Howard AD. 1992. Geomorphological Perspectives. In Lowland Floodplain Rivers, Carling, P., Petts, GE (eds), Wiley and Sons: Chichester, UK.

$\mathrm{Hu}$ C, Chen J, Liu D. 2006. Study on the features of a cross-section's profile in the lower 
Yellow River under the conditions of variable incoming water and sediment. Journal of Hydraulic Engineering 11: 1283-1289. (in Chinese)

$\mathrm{Hu}$ Y, Zhang X. 2006. Brief discussion on the secondary perched river, Journal of Sediment Research 52(32): 1-9. (in Chinese)

Hudson P, Middelkoop, H (eds.). 2015. Geomorphic Approaches to Integrated Floodplain Management of Lowland Fluvial Systems in North America and Europe. Springer-Verlag: New York.James CS. 1985. Sediment transfer to overbank sections. Journal of Hydraulic Research 23: 435-452.

Karim F, Petheram C, Marvanek S, Ticehurst C, Wallace J, Hasan M. 2016. Impact of climate change on floodplain inundation and hydrological connectivity between wetlands and rivers in a tropical river catchment. Hydrological Processes 30(10): 1574-1593.

Klasz G, Reckendorfer W, Gabriel H, Baumgartner C, Schmalfuss R, Gutknecht D. 2014. Natural levee formation along a large and regulated river: the Danube in the national Park Donau-Auen, Austria. Geomorphology 215(12):20-33

Lambert CP, Walling DE. 1987. Floodplain sedimentation: a preliminary investigation of contemporary deposition within the lower reaches of the River Culm, Devon, UK. Geografiska Annaler. Series A: Physical Geography 69A (3-4): 393-404.

Latrubesse EM, Franzinelli E. 2002. The Holocene alluvial plain of the middle Amazon River, Brazil. Geomorphology 44: 241-257.

Latrubesse EM. 2012. Amazon Lakes. In Encyclopedia of Lakes and Reservoirs, Bengtsson L, Herschy RW, Fairbridge RW (eds). Springer: Netherlands; 13-26.

Latrubesse EM. 2015. Large rivers, megafans and other quaternary avulsive fluvial systems: a potential 'who's who' in the geological record. Earth-Science Reviews 146: 1-30.

Lewin J, Ashworth PJ. 2014a. The negative relief of larger floodplains. Earth-Science Reviews 129: 1-23.

Lewin J, Ashworth PJ. 2014b. Defining large river channel patterns: alluvial exchange and plurality. Geomorphology 215: 83-98

Li S, Long Y. 1994. A suitable method and its application for calculating sediment discharge in the Lower Yellow River. Journal of Sediment Research 3: 35-40. (in Chinese)

Li Y, Chen J, Ren Y. 2011. Study on the evolution characteristic of over-bank flooding in Huayuankou - Sunkou reach of the Lower Yellow River. Yellow River 33(8): 23-24. (in Chinese)

Liu X, Shen G, Zhang Y, Jiang N. 2009. Features and regulation of high-sediment floods in the Lower Yellow River. Journal of Beijing Normal University (Natural Science) 45(5/6): 490-494.

Liu Y, Han S, Wu Z. 1986. A method for calculating the erosion and sedimentation in the Lower Yellow River. Yellow River Institute of Hydraulic Research 5: 65-68. (in Chinese)

Ma Y, Huang HQ, Nanson GC, Li Y, Yao W. 2012. Channel adjustments in response to the operation of large dams: The upper reach of the lower Yellow River. Geomorphology 147: 35-48.

Magilligan FJ, Philips JD, James A, Gomez B. 1998. Geomorphic and sedimentological controls on the effectiveness of an extreme flood. Journal of Geology 106:87-95.

Marriott S.1992. Textural analysis and modeling of a flood deposit: River Severn, UK. Earth 
Surface Processes and Landforms 17(7): 687-697.

Maurice-Bourgoin L, Martinez JM, Grelaud J, Filizola N, Resens G, Boaventura. 2005. The role of floodplains in the hydrology and sediment dynamics of the Amazon River, Brazil. Sediment Budgets I (Proceedings of Symposium S1 held during the 7th IAHS Scientific Assembly at Foz do Iguaçu, Brazil, April 2005). IAHS Publ. 291.

Maurice-Bourgoin L, Bonnet M-P, Martinez J-M, Kosuth P, Cochonneau G, Moreira-Turcq P, Guyot J-L, Vauchel P, Fiozol N, Seyler P. 2007. Temporal dynamics of water and sediment exchanges between the Curuaí floodplain and the Amazon River, Brazil. Journal of Hydrology 335: 140-156.

Maurice-Bourgoin L, Martinez J-M, Grelaud J, Filizola N, Boaventura GR. 2005. The role of floodplains in the hydrology and sediment dynamics of the Amazon River, Brazil. IAHS Publication 291: 1-10.

Mertes LAK. 1994. Rates of floodplain sedimentation on the central Amazon River. Geology 22:171-174.

Nanson GC, Croke JC. 1992. A genetic classification of floodplains. Geomorphology 4(6), 459-486.

New A, Middelkoop H. 1995. Floodplain sedimentation: quantities, patterns and processes. Earth Surface Processes and Landforms 20: 481-499.

Newson MD. 1989. Flood effectiveness in river basins: progress in Britain in a decade of drought. In Floods: Hydrological, Sedimentological and Geomorphological Implications, Bevan K, Carling P. (eds). Wiley: Chichester, 151-169.

Nicholas AP, Walling DE. 1997. Investigating spatial patterns of medium-term overbank sedimentation on floodplains: a combined numerical modeling and radiocasesium-based approach. Geomorphology 19:133-150

Nicholas AP, Walling DE. 1997. Investigating spatial patterns of medium-term overbank sedimentation on floodplains: a combined numerical modeling and radiocaesium-based approach. Geomorphology 19:133-150

Olariu C, Bhattacharya JP, Leybourne MI, Boss SK, Stern RJ. 2012. Interplay between river discharge and topography of the basin floor in a hyperpyncnal lacustrine basin. Sedimentology 59: 704-728.

Pan X, Li Y, Zhang X. 2006. Evolution of the Lower Yellow River after the Construction of the Sanmenxia Reservoir. Yellow River Water Conservancy Press: Zhengzhou, 110-112. (in Chinese)

Parker DJ. 1995. Floodplain development policy in England and Wales. Applied Geography 15: 341-363.

Pizzuto JE. 1987. Sediment diffusion during overbank flows. Sedimentology 34: 301-317.

Qi P, Gao H, Peng H. 2005. No inexorable relationship between floodplain and scoured channel, Yellow River 27(10): 17-20. (in Chinese)

Qian N, Zhang R, Zhou Z. 1987. Fluvial Processes. Science Press: Beijing. (in Chinese)

Qian N, Zhou W. 1965. Fluvial Processes of the Lower Yellow River. Science Press: Beijing. (in Chinese)

Ritter DF, Kinsey WF, Kaufman ME. 1973. Overbank sedimentation in the Delaware River Valley during the last 6000 years, Science 179: 374-375.

Rowland JC, Dietrich WE, Stacey MT. 2010. Morphodynamics of subaqueous levee 
formation: insights into river mouth morphologies arising from experiments. Journal of Geophysical Research 115: 1-20.

Rowland JC, Lepper K, Dietrich WE, Wilson CJ, Sheldon R. 2005. Tie channel sedimentation rates, oxbow formation age and channel migration rate from optically stimulated luminescence (OSL) analysis of floodplain deposits. Earth Surface Processes and Landforms 30: 1161-1179.

Rozo MG, Nogueira ACR, Castro CS. 2014. Remote sensing-based analysis of the planform changes in the Upper Amazon river over the period 1986-2006. Journal of South American Earth Sciences 51: 28-44.

Shen G, Jiang N, Zhang Y, Shang H. 2006. Comparison of the calculated sedimentation amount by different methods in the Lower Yellow River. Journal of Sediment Research 2: 32-37. (in Chinese)

Shen Z, Törnqvist TE, Mauz B, Chamberlain EL, Nijhuis AG, Sandoval L. 2015. Episodic overbank deposition as a dominant mechanism of floodplain and delta-plain aggradation. Geology 43: 875-878.

Toonen WHJ, Kleinhans MG, Cohen KM. 2012. Sedimentary architecture of abandoned channel fills. Earth Surface Processes and Landforms 37: 459-472.

Trigg MA, Bates PD, Wilson MD, Schumann G, Baugh C. 2012. Floodplain channel morphology and networks of the middle Amazon River. Water Resources Research 48 (10):188-190.

van de Lageweg WI, Van Dyke WM, Kleinhans MG. 2013. Morphological and stratigraphical signatures of floods in braided gravel-bed river revealed from flume experiments. Journal of Sedimentary Research 83: 1032-1045.

Walling DE, He Q, Nicholas AP. 1996. Floodplains as suspended sediment sinks. In Floodplain Processes, Anderson MG, Walling DE, Bates PD (eds.). Wiley: Chichester, 399-440.

Walling DE, Owens PN, Leeks GJL. 1999. Rates of contemporary overbank sedimentation and sediment storage on the floodplains of the main channel systems of the Yorkshire Ouse and River Tweed, UK. Hydrological Processes 13: 993-1009.

Wu B, Wang G, Ma J, Zhang R. 2005. Case study: river training and its effects on fluvial processes in the lower Yellow River, China. Journal of Hydraulic Engineering, ASCE 131(2): 85-96.

Xia J, Li X, Li T, Zhang X, Zong Q. 2014. Response of reach-scale bankfull channel geometry to the altered flow and sediment regime in the lower Yellow River. Geomorphology 213: 255-265.

$\mathrm{Xu}$ J. 2004. A study of anthropogenic seasonal rivers in China. Catena 55: 17-32.

Yao W, Li Y, Zhang Y. 2007. Key Technologies for Maintaining the Basic Flood Discharging and Sediment Transport in the Lower Yellow River. Science Press: Beijing, 69-77. (in Chinese)

Zhang M, Huang H, Zhang X. 2016. A study of the characteristics of sedimentation during overbank floods in the lower Yellow River. Advances in Water Science 27(2): 165-175. (in Chinese)

Zhang R (ed.). 1998. River Sediment Transport Dynamics, 2nd edition, China Water and Power Press: Beijing, 230pp. 
Zhang Y, Liu X, Zhang X. 2006. Regulation indexes of the medium flood in the Lower Yellow River. Journal of Sediment Research 12: 1-5. (in Chinese)

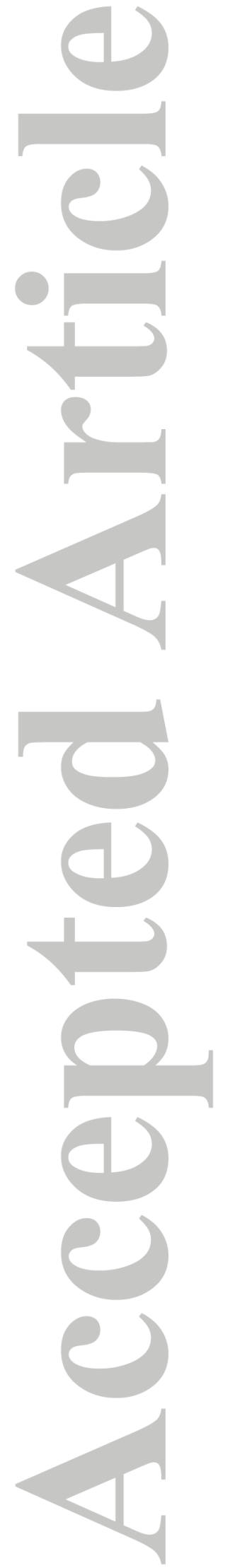




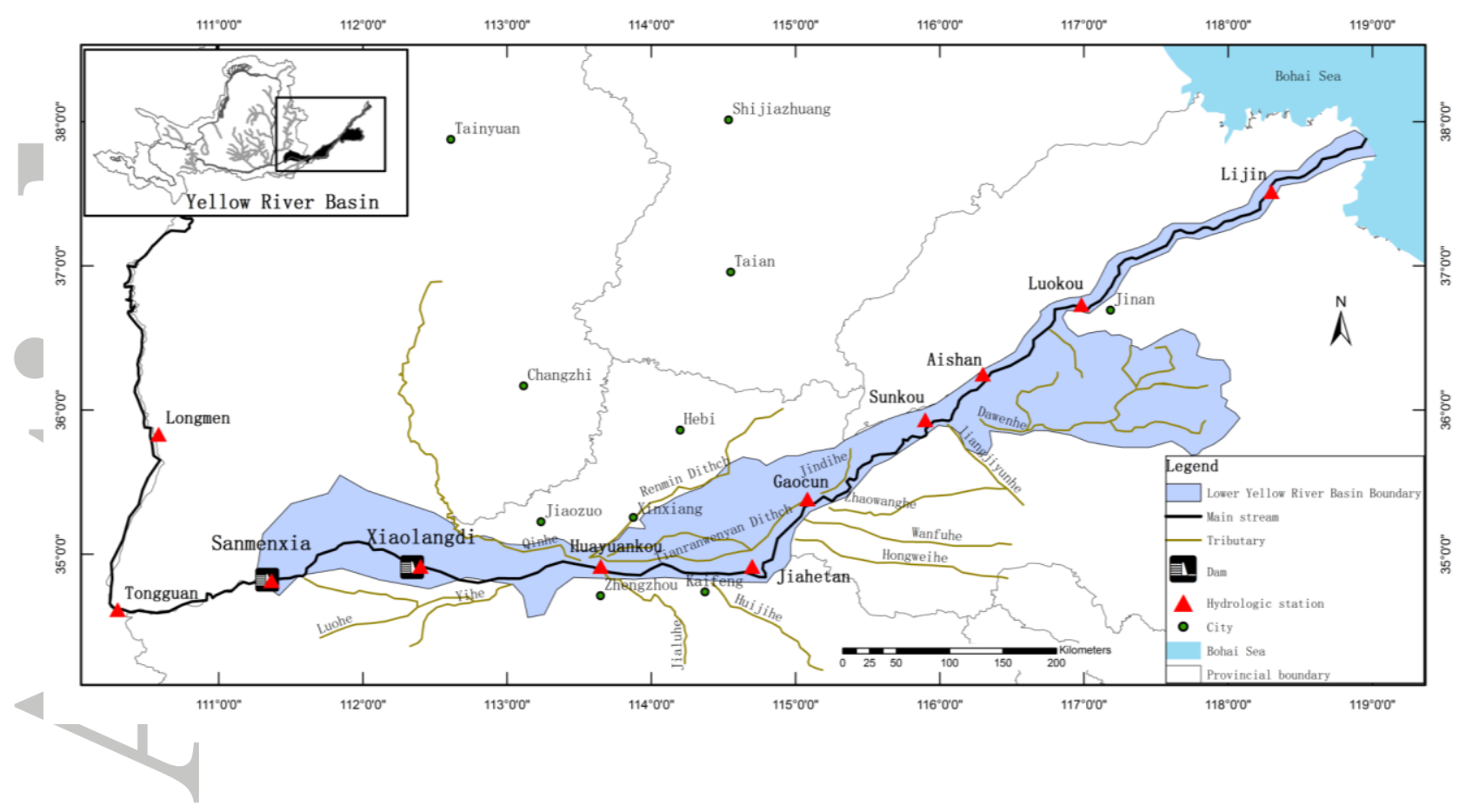

Fig. 1 Location of the Lower Yellow River

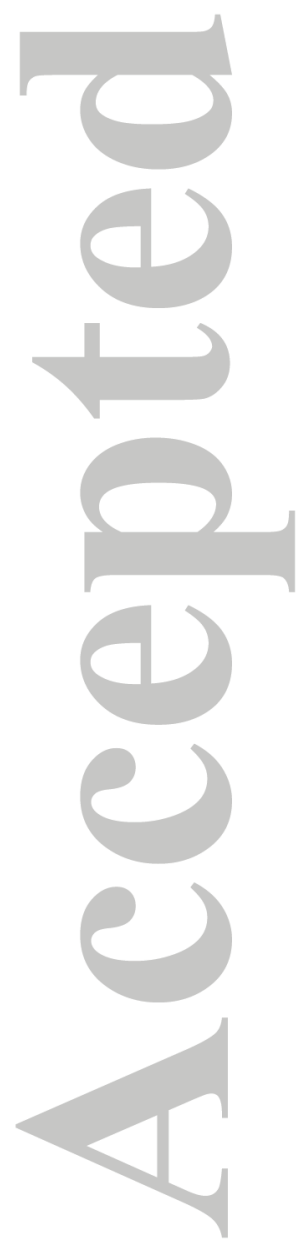




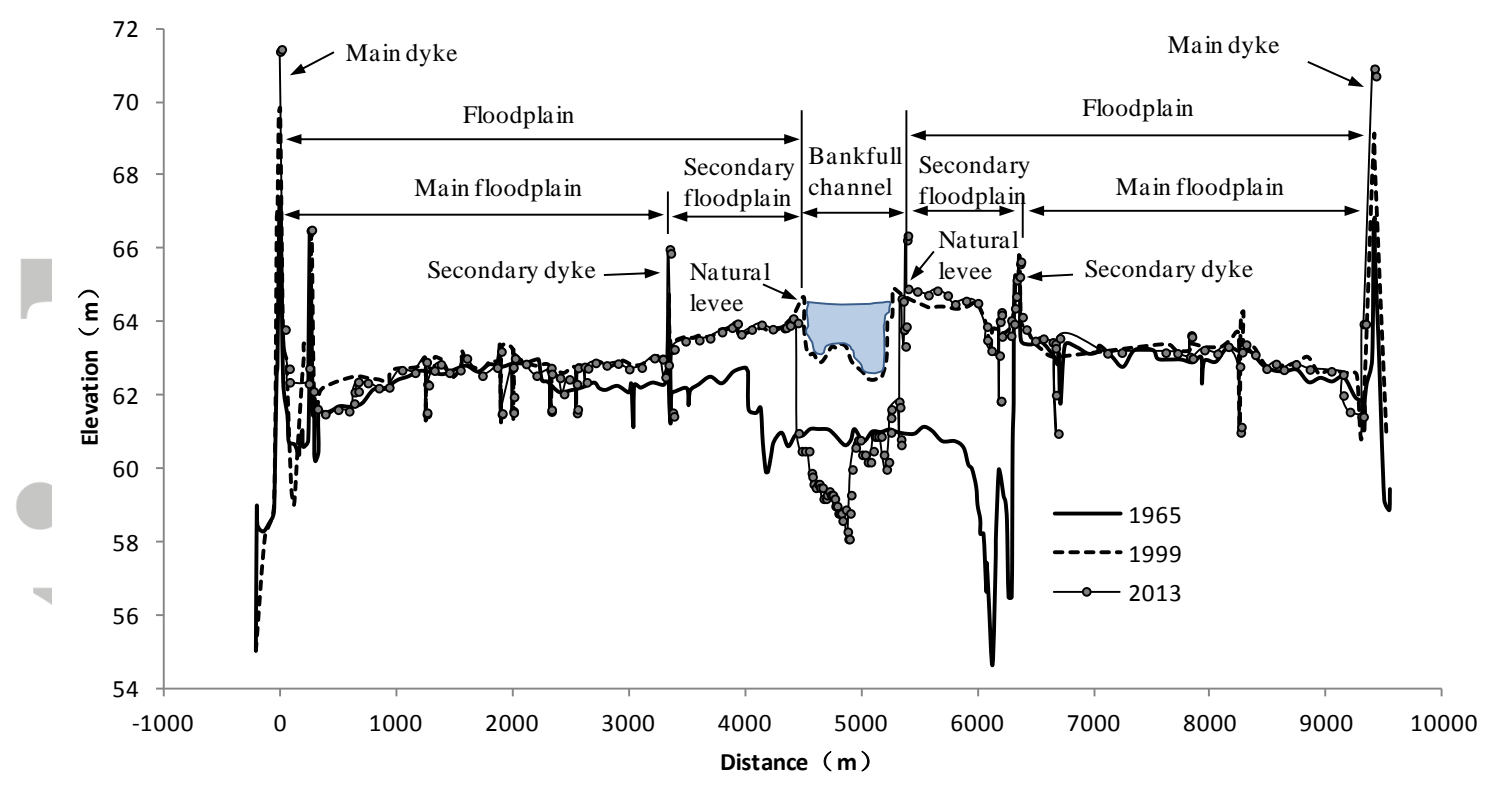

Fig. 2 A representative cross-profile of the Lower Yellow River

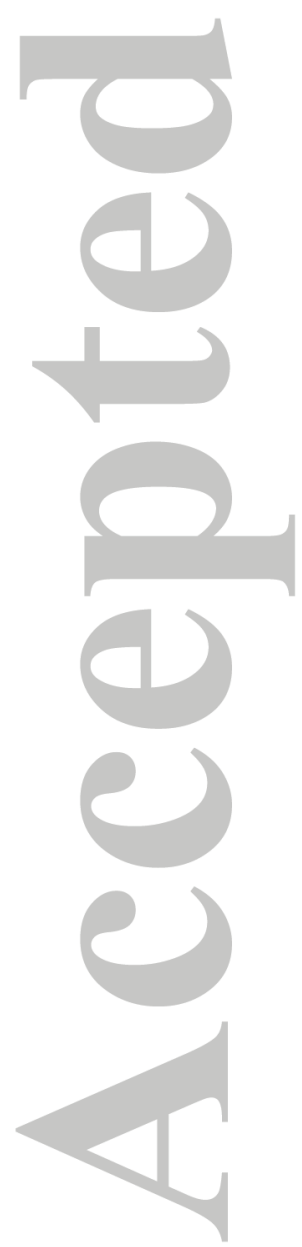




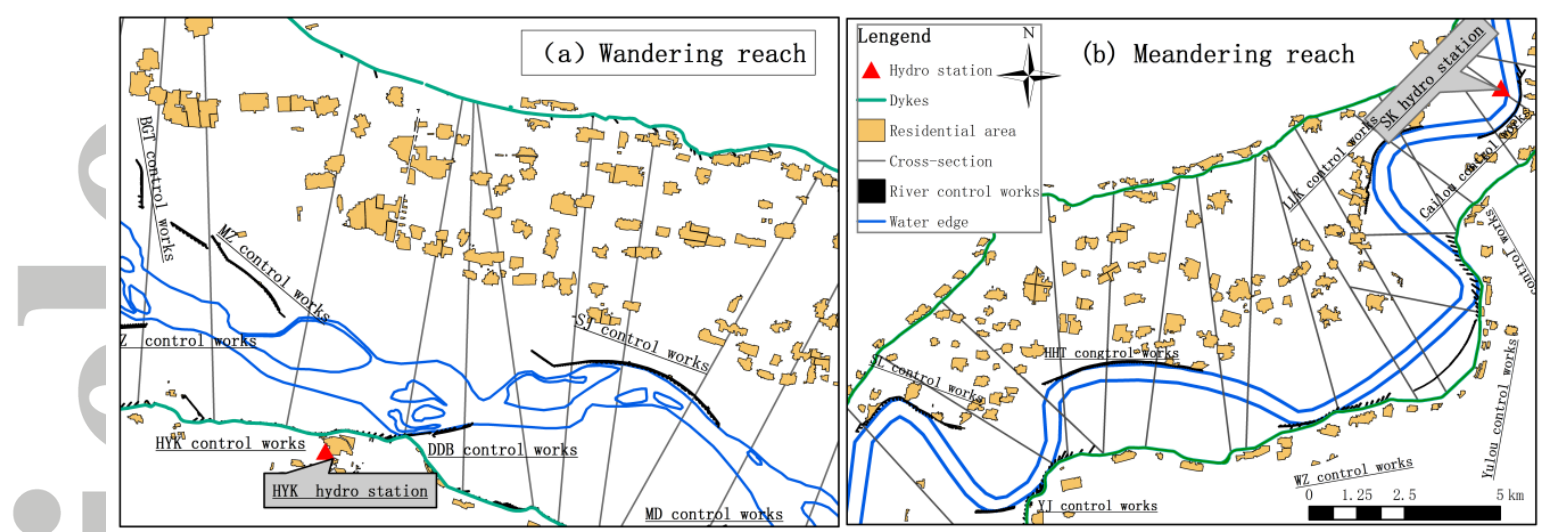

Fig. 3 Representative wandering and meandering reaches of the Lower Yellow

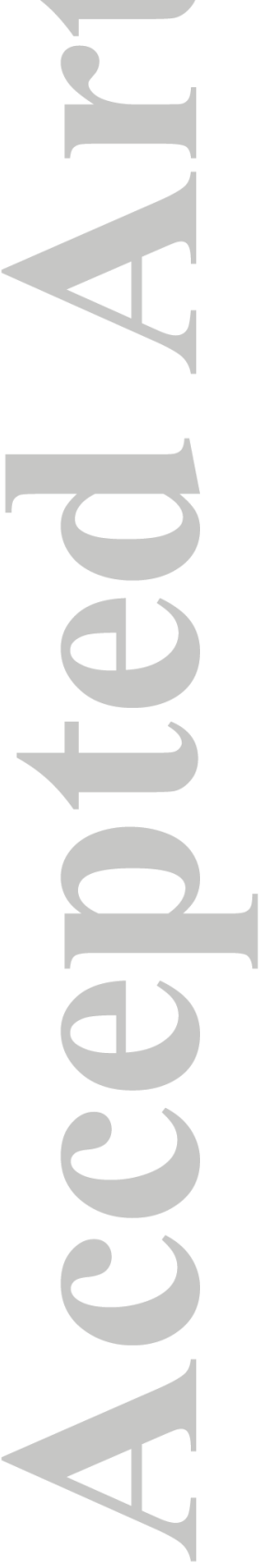

River: (a). the wandering reach; (b). the meandering reach). 


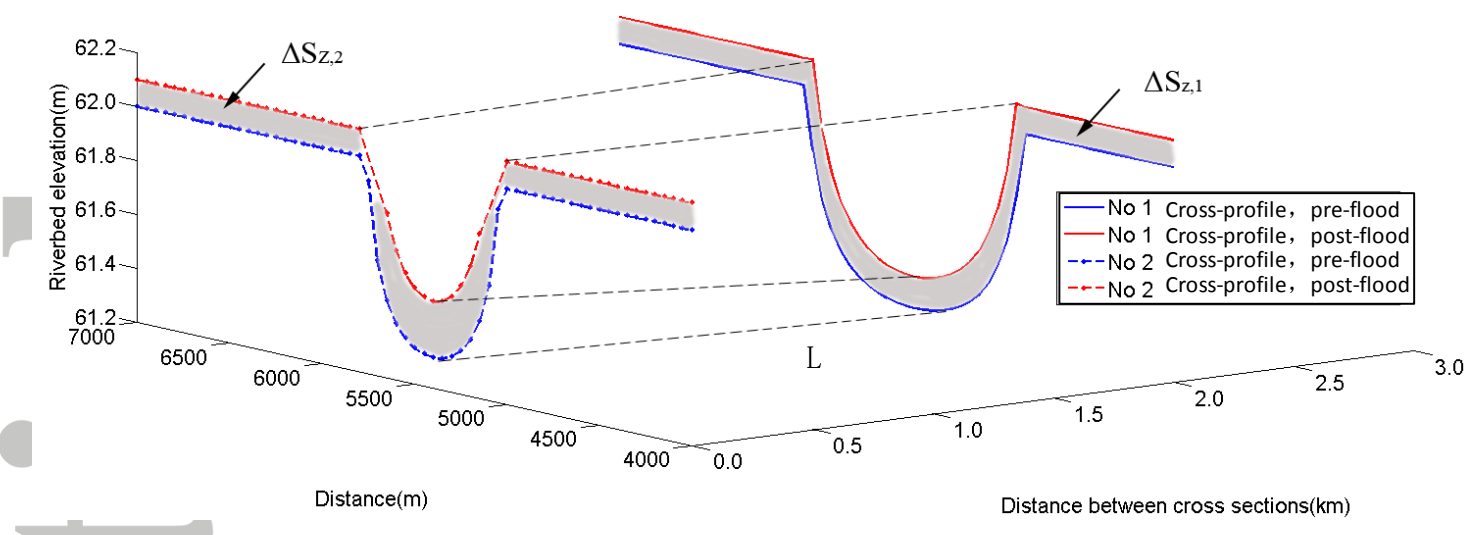

Fig. 4 A schematic diagram of the cross-profile method for calculating the volume of erosion/deposition. 


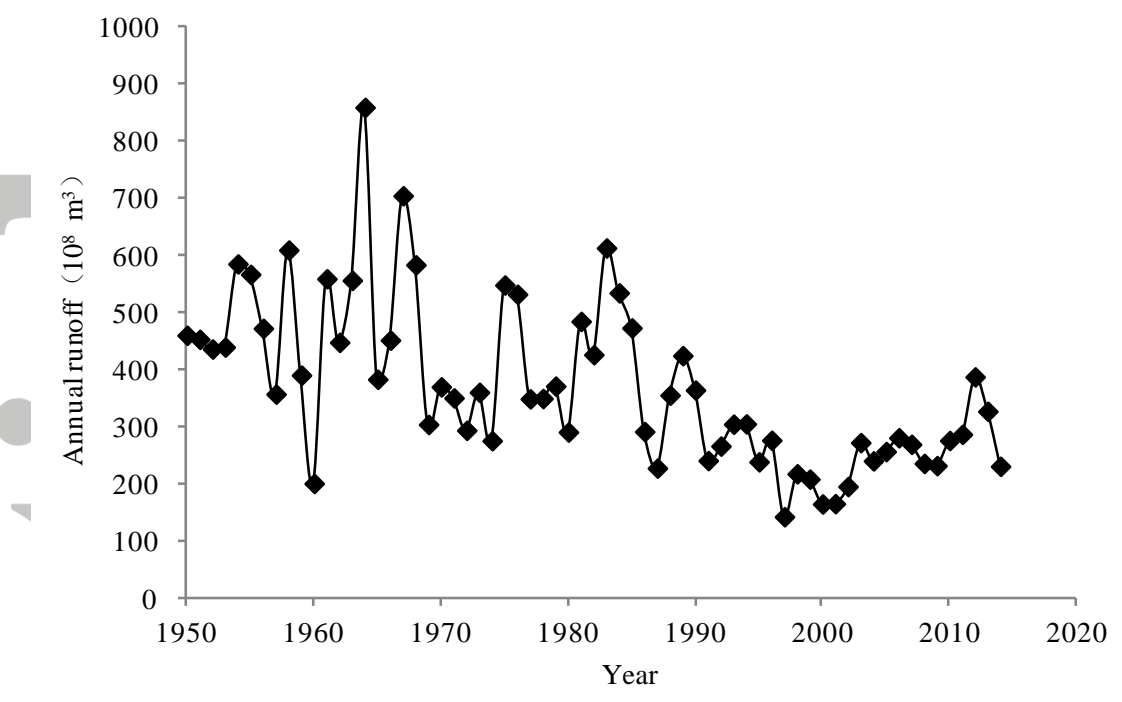

(a)

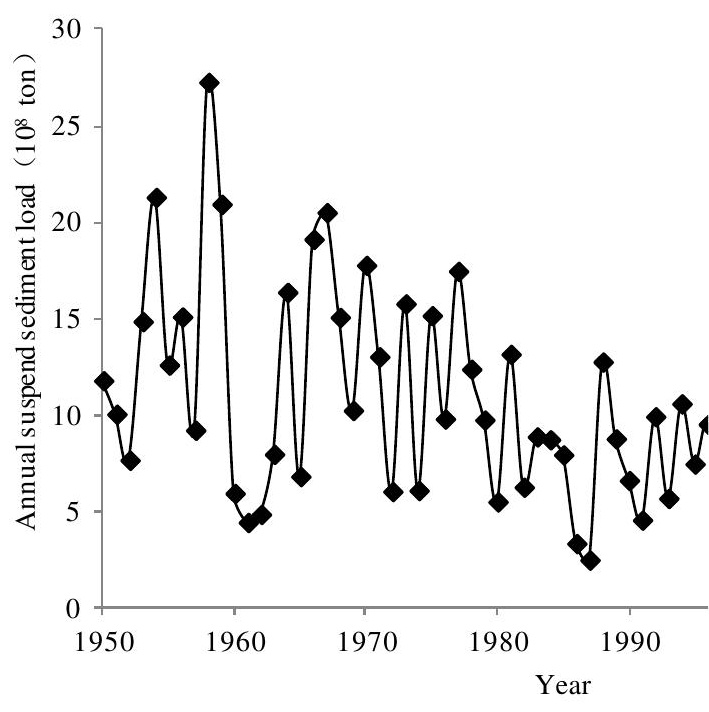

(b)

Fig. 5 Variations of annual runoff and suspended sediment load measured at Huayuankou gauging station

during 1950-2014: (a). annual runoff; (b). annual suspended sediment load. 


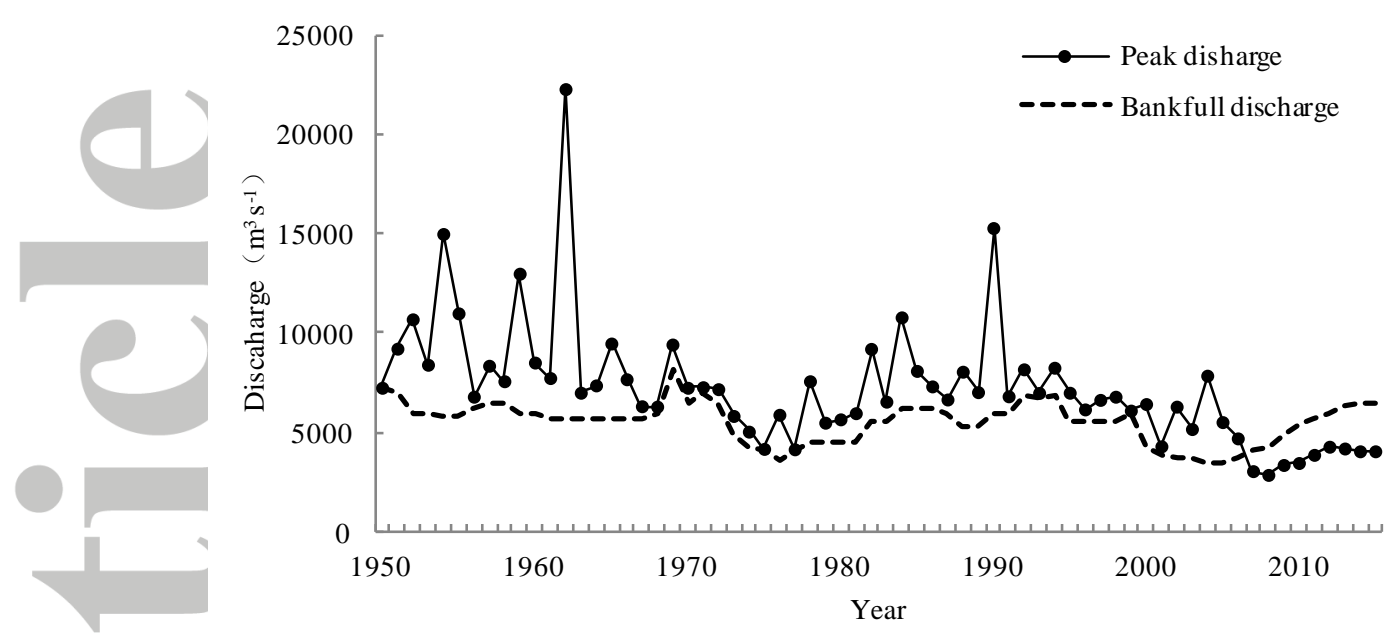

Fig. 6 Peak and bankfull discharges measured at Huayuankou gauging station $+$ since 1950

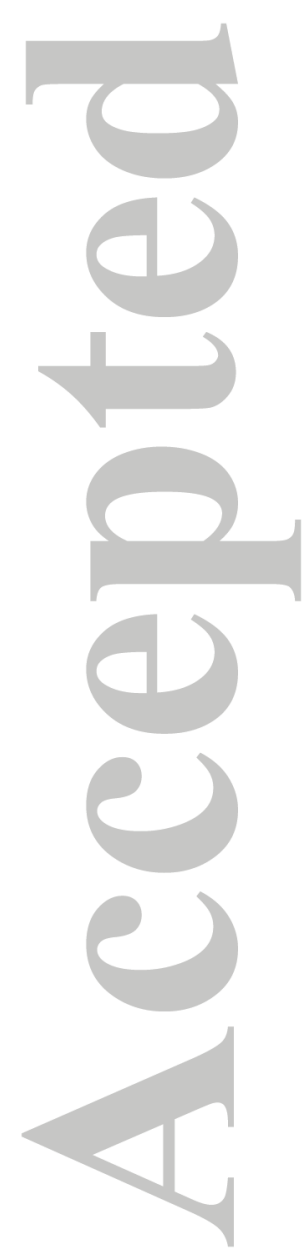

This article is protected by copyright. All rights reserved. 

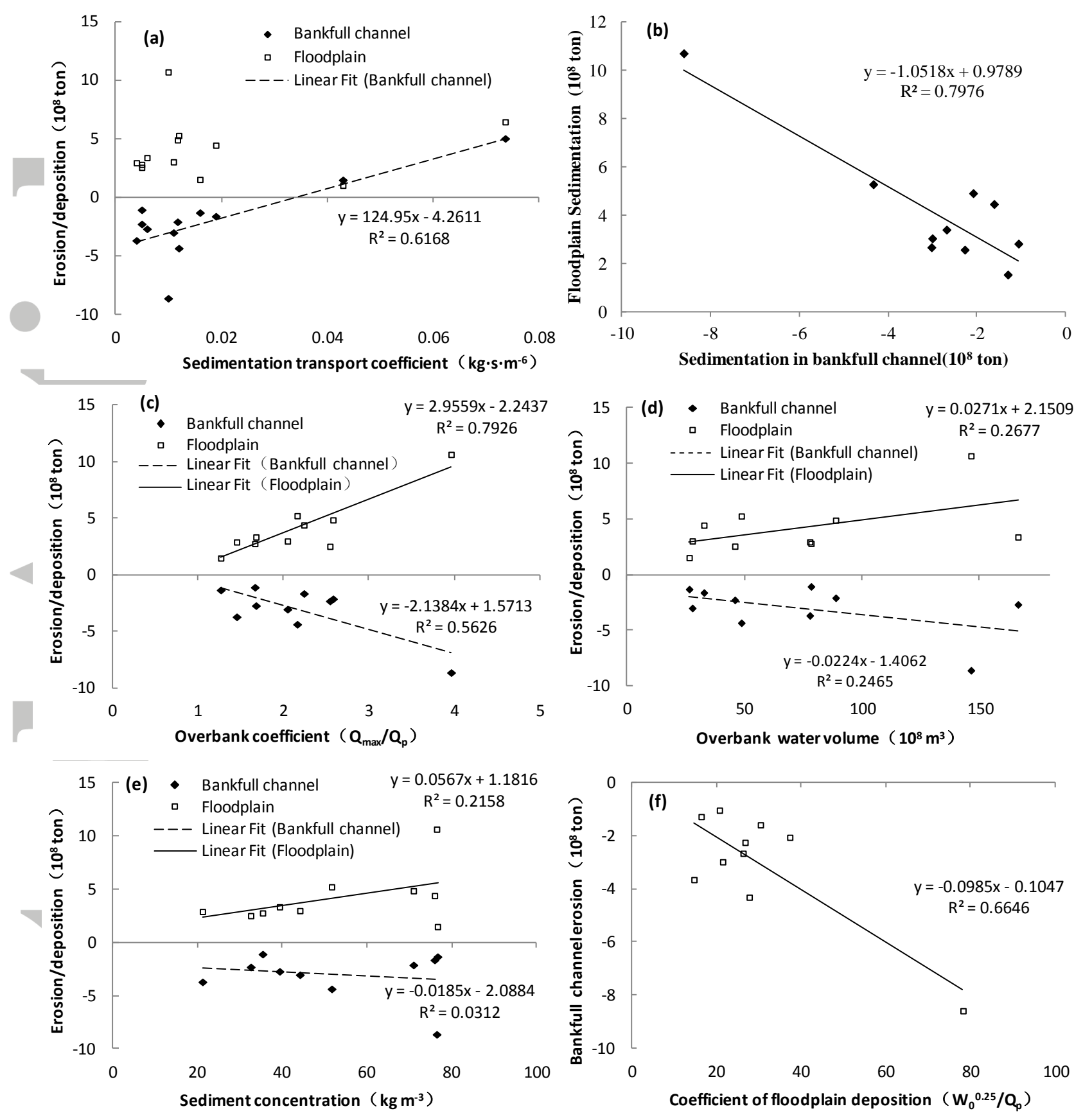

Fig. 7 Erosion/deposition in the channel system of the Lower Yellow River during large overbank floods: (a). effect of sediment transport coefficient; (b). interaction between the bankfull channel erosion and floodplain deposition; (c). effect of overbank coefficient $\left(Q_{\max } / Q_{\mathrm{p}}\right) ;(\mathrm{d})$. effect of overbank water volume; (e). effect of suspended sediment concentration of flow; (f). effect of floodplain deposition coefficient. 

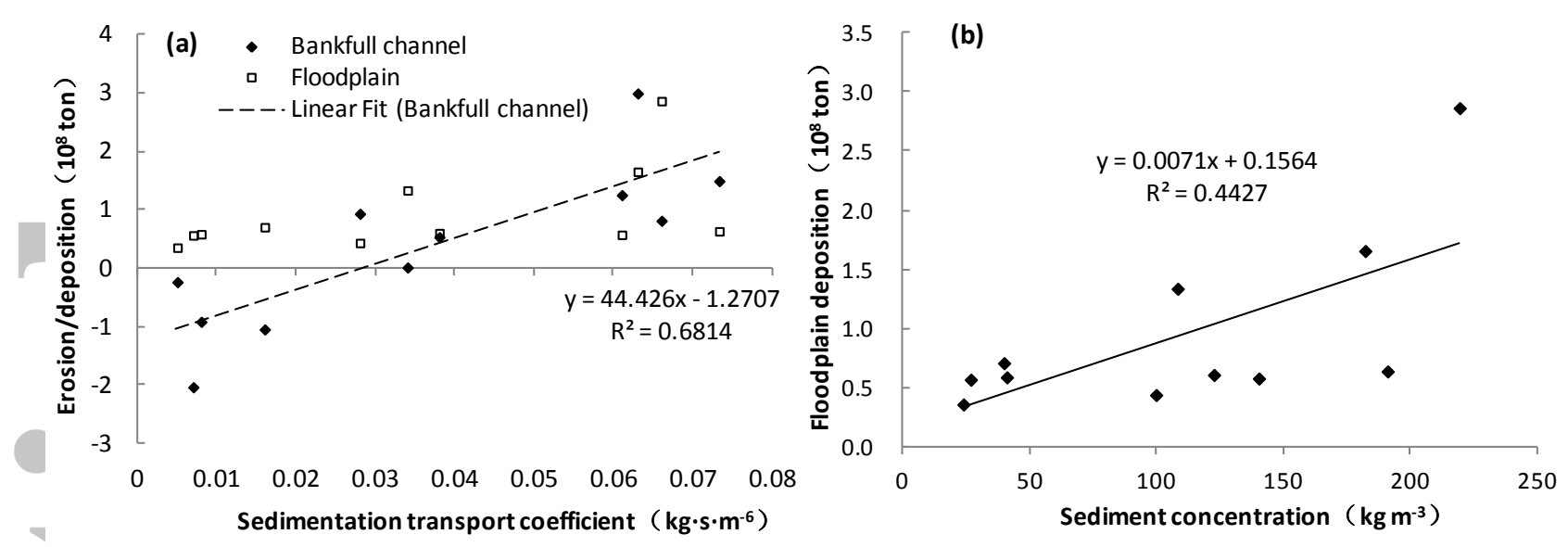

Fig. 8 Relationship between erosion/deposition in the Lower Yellow River and sediment transport coefficient during small overbank floods: (a). erosion/deposition in the bankfull channel and on the secondary floodplain; (b). erosion in the bankfull channel.

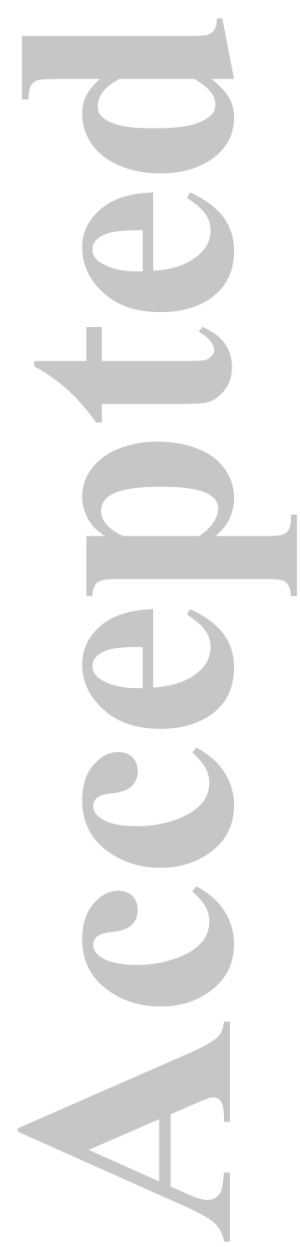




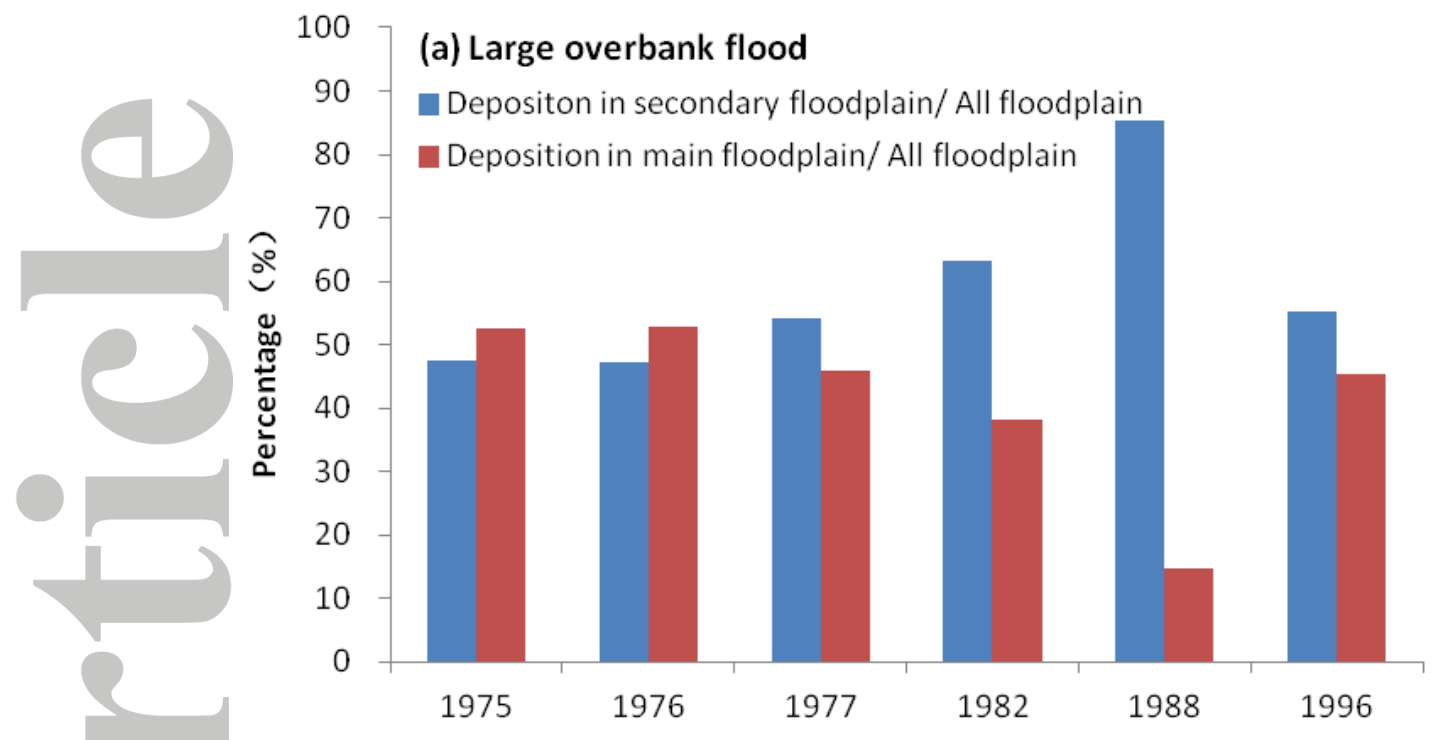

(b) Small overbank flood
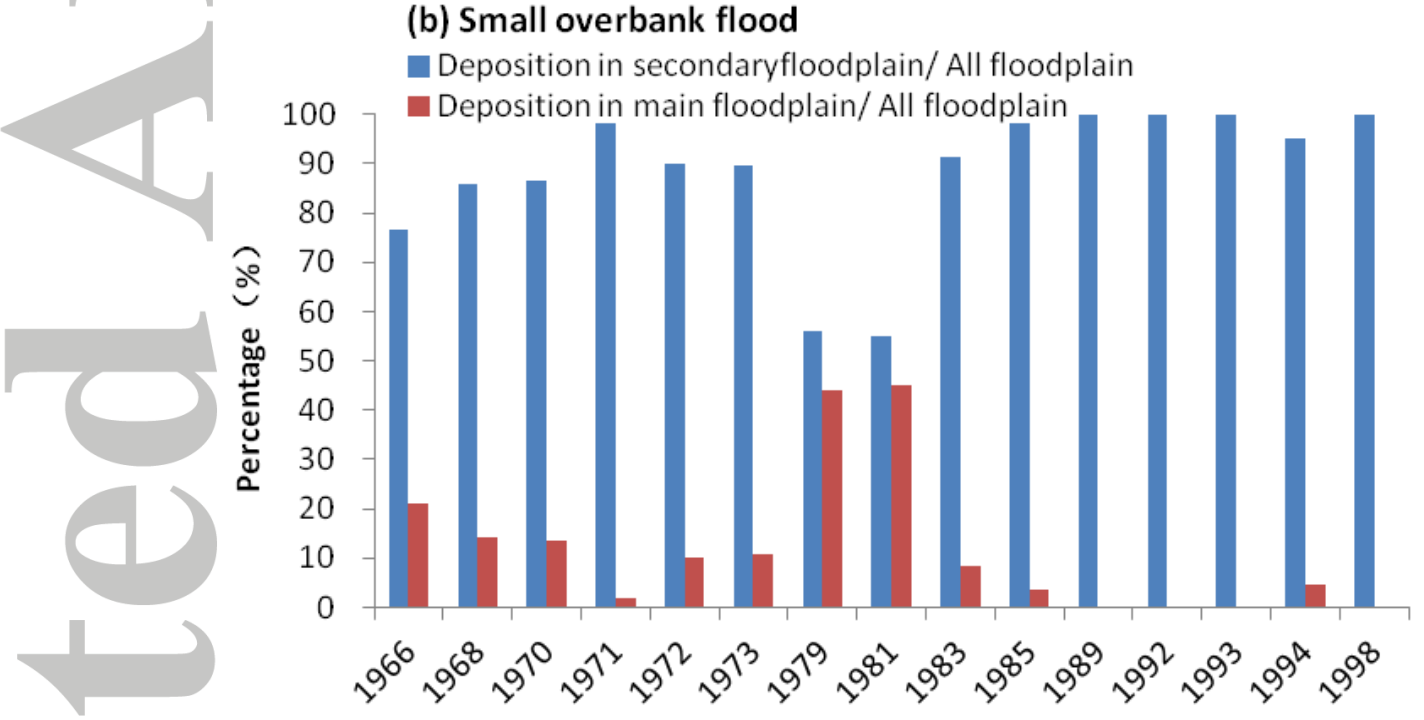

Fig. 9 Percentages of the sediment deposition in the main floodplain to the deposition in the main and secondary floodplains: (a). during large overbank floods; (b). during small overbank floods. 


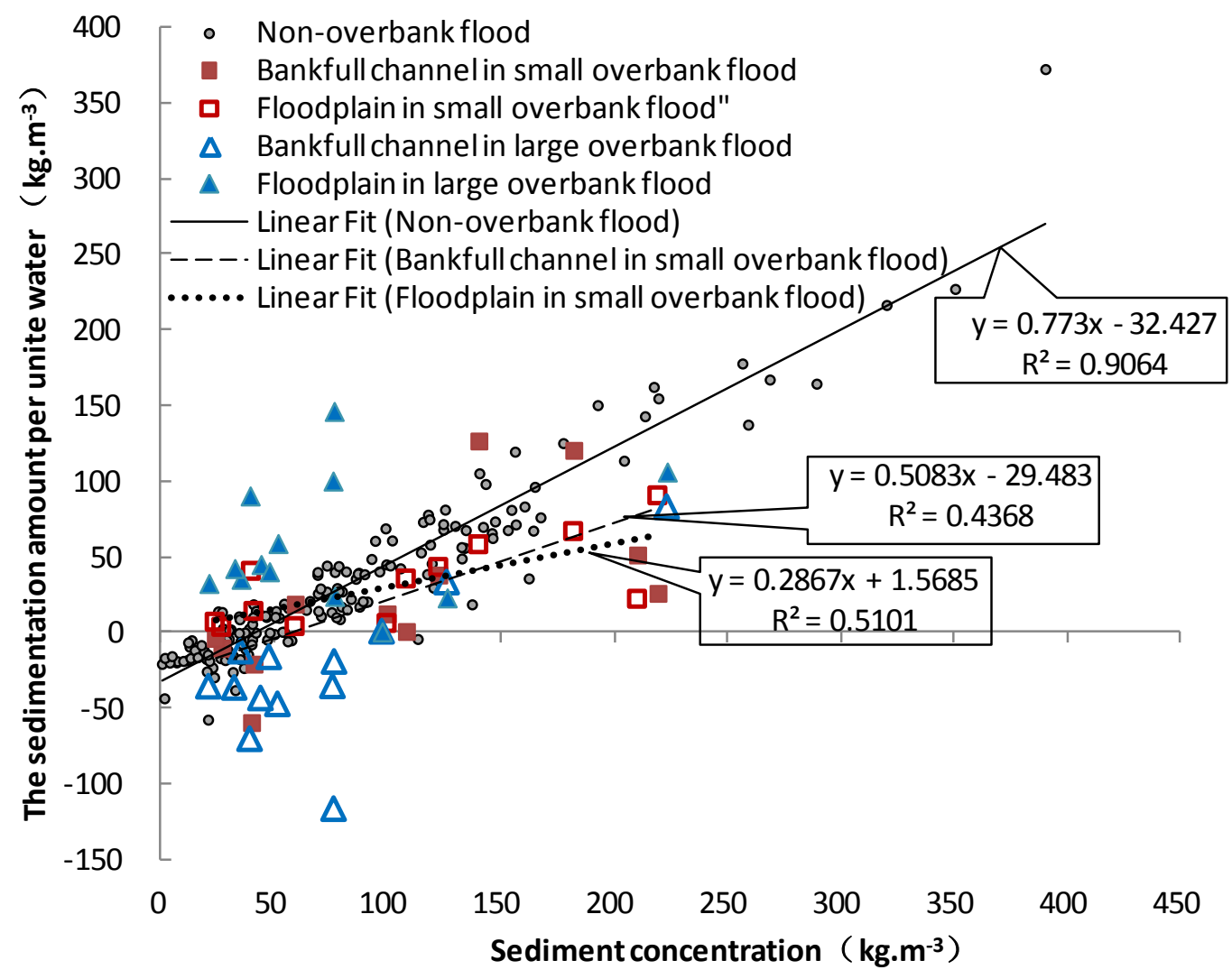

Fig. 10 Relationship between sedimentation per unit flow discharge and sediment transport concentration for different types of floods in the Lower Yellow River

This article is protected by copyright. All rights reserved. 

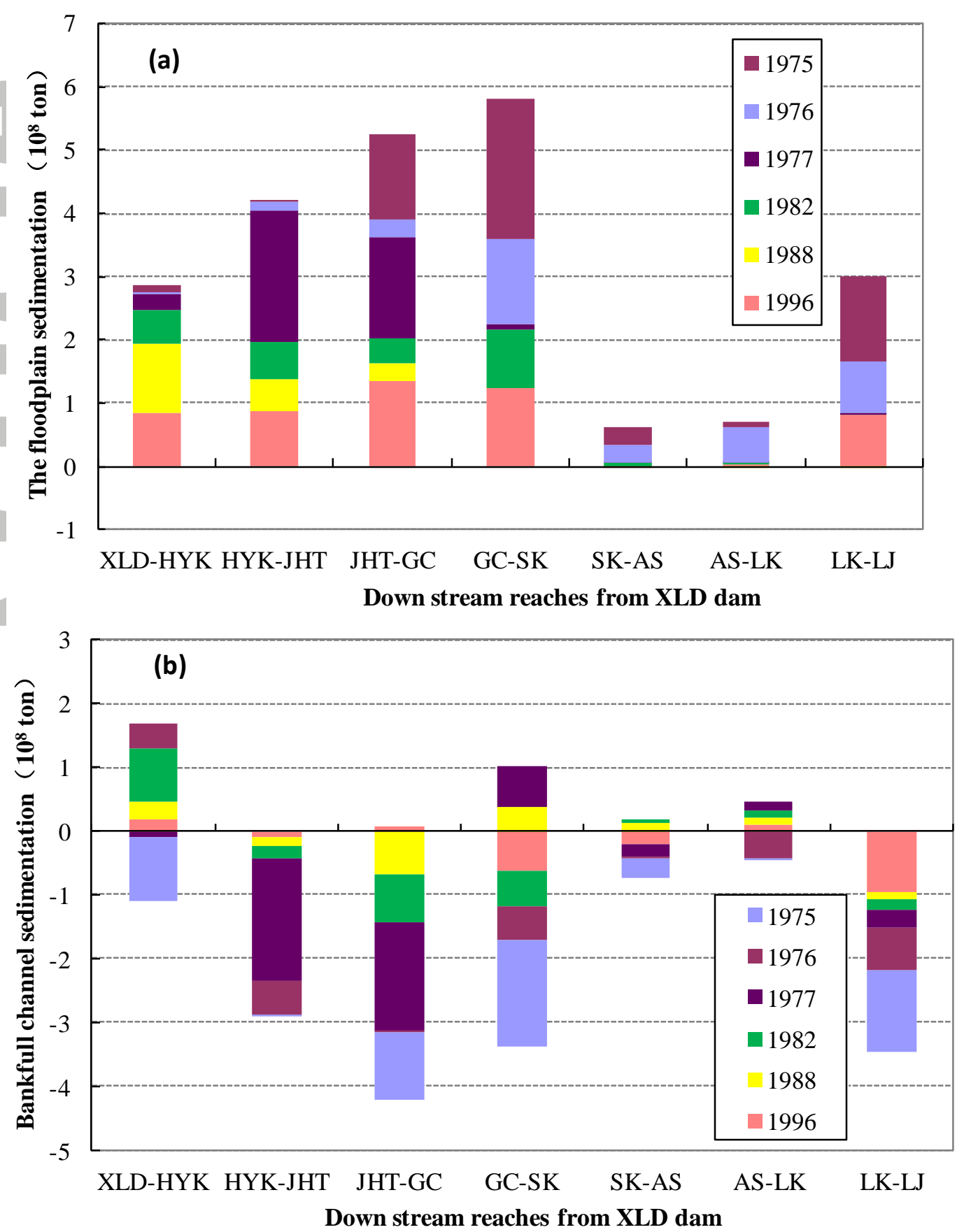

Fig. 11 Sedimentation in different reaches of the Lower Yellow River during large overbank floods (XLD-HYK, HYK-JHT, JHT-GC, GC-SK, SK-AS, AS-LK and LK-LJ are the abbreviations of the reaches of Xiaolangdi to Huayuankou, Huayuankou to Jiahetan, Jiahetan to Gaocun, Gaocun to Sunkou, Sunkou to Aishan, Aishan to Luokou, and Luokou to Lijin, respectively): (a). sedimentation on the floodplain; (b). sedimentation in the bankfull channel. 

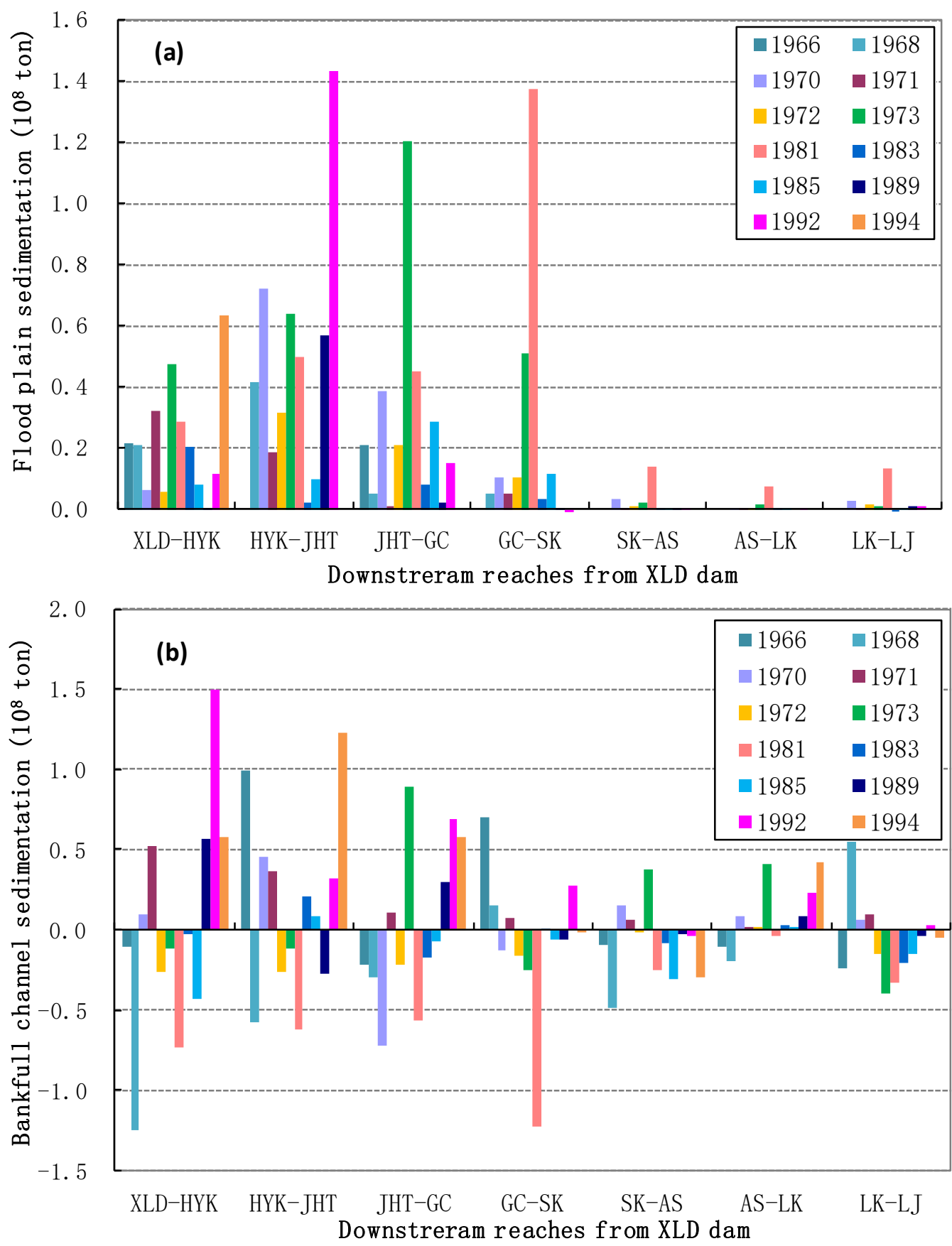

Fig. 12 Sedimentation in different reaches of the Lower Yellow River during small overbank floods (abbreviated reach names are given in the caption of Fig. 11): (a). sedimentation on the floodplain; (b). sedimentation in the bankfull channel. 


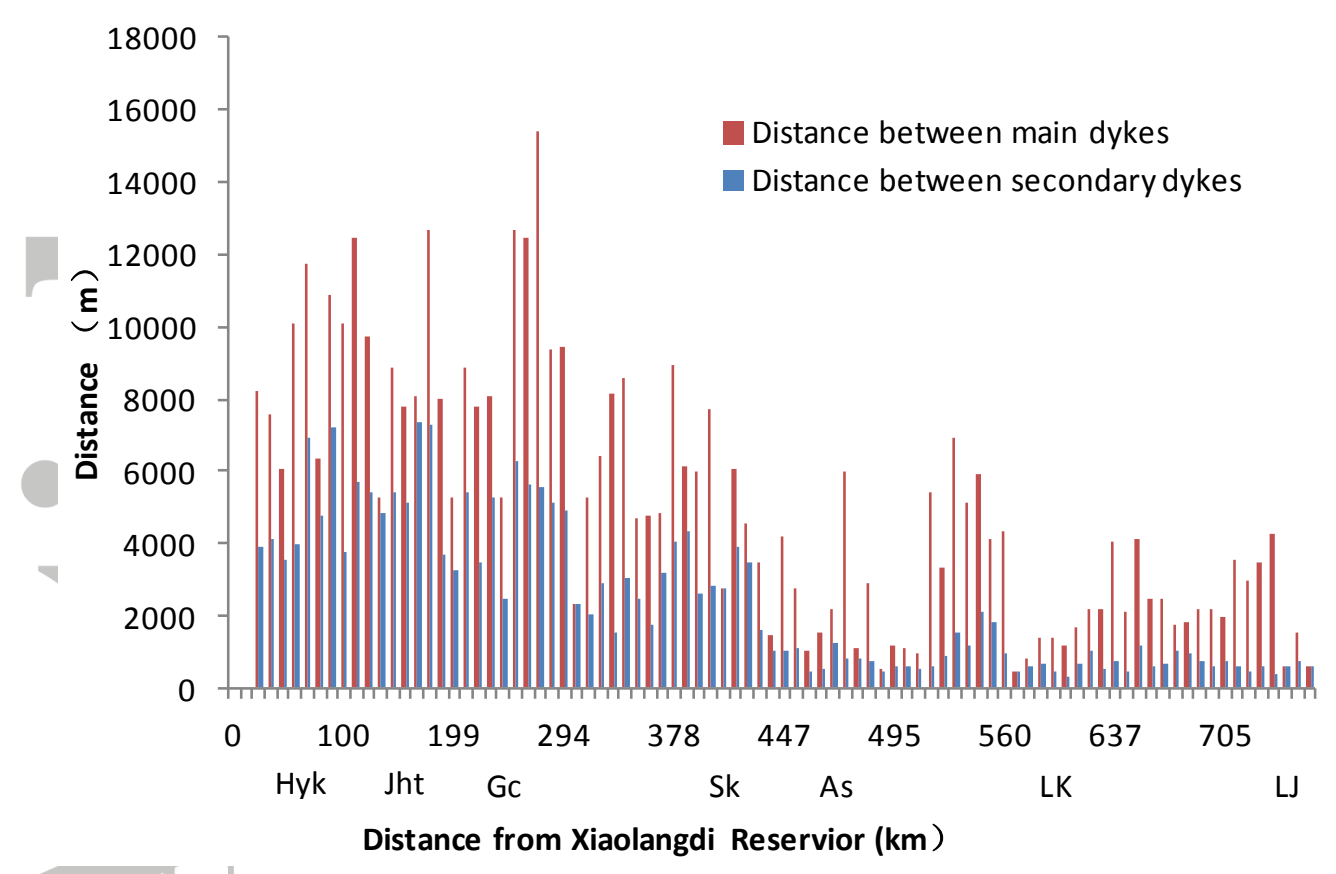

Fig. 13 Distance between dykes on the opposite sides of the Lower Yellow River (abbreviated reach names are given in the caption of Fig. 11) 


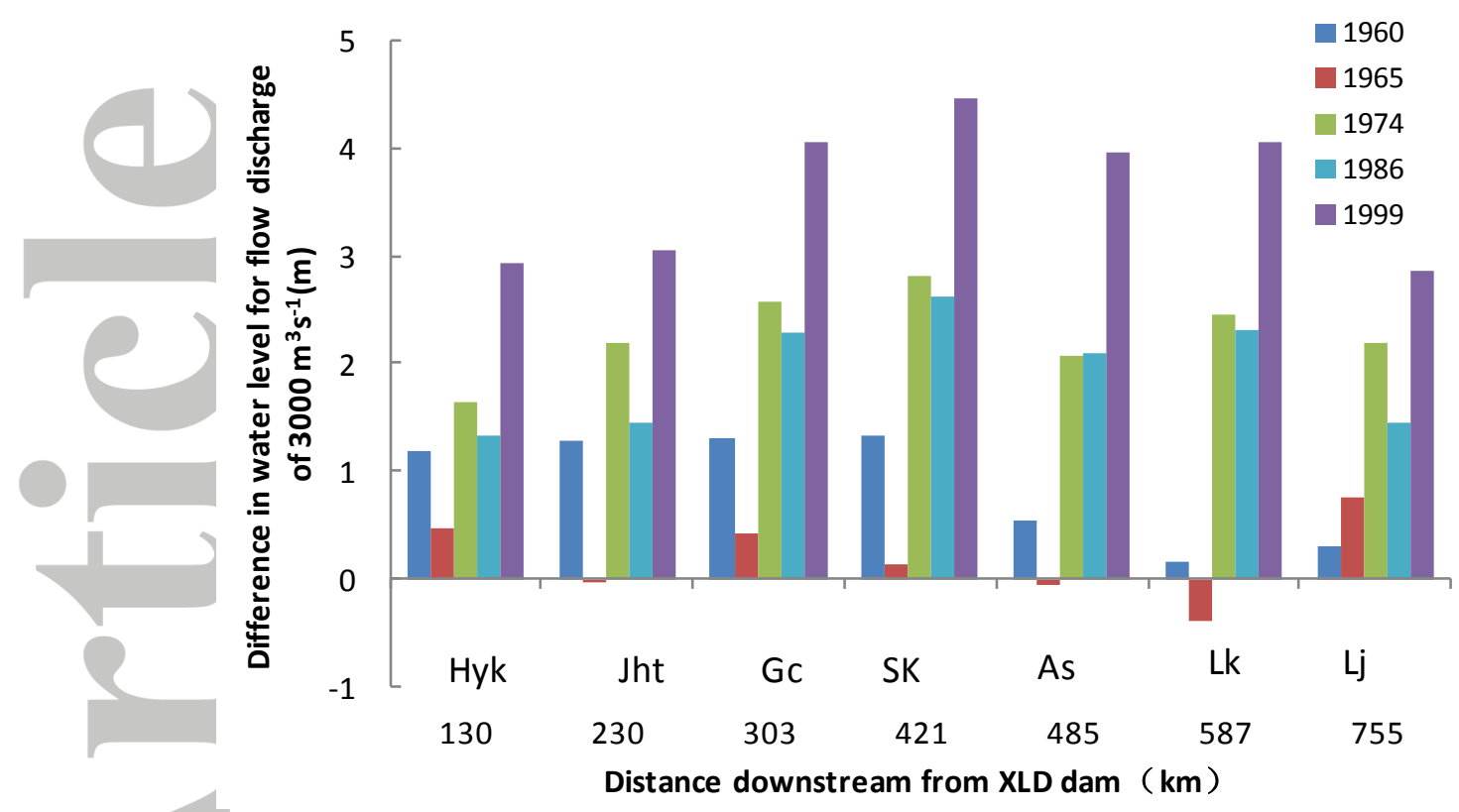

Fig. 14 Differences between water levels under the same flow discharge of

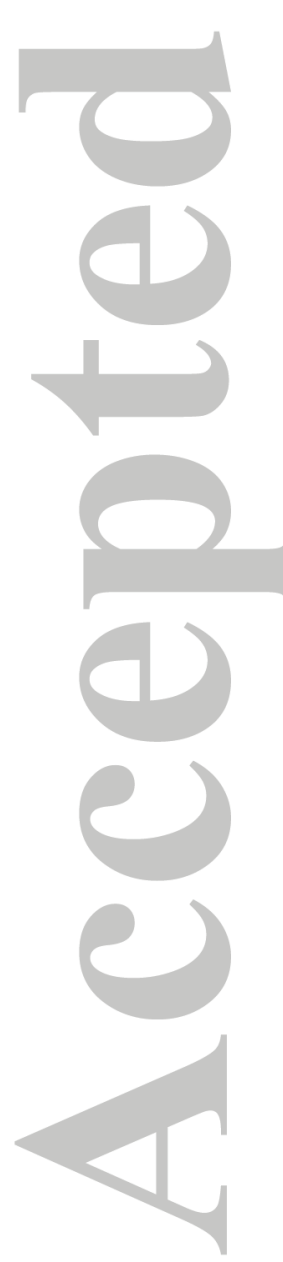
$3,000 \mathrm{~m}^{3} \mathrm{~s}^{-1}$ 
Table 1 Characteristics of large overbank floods at Huayuankou gauging station

\begin{tabular}{|c|c|c|c|c|c|c|}
\hline Year & $\begin{array}{c}\text { Period } \\
(\mathrm{mm} . \mathrm{dd})\end{array}$ & $\begin{array}{c}\text { Peak discharge } \\
Q_{\max }\left(\mathrm{m}^{3} \mathrm{~s}^{-1}\right)\end{array}$ & $\begin{array}{c}\text { Sediment concentration } \\
\text { of peak flow }\left(\mathrm{kgm}^{-3}\right)\end{array}$ & $\begin{array}{c}\text { Bankfull discharge } \\
Q_{\mathrm{p}}\left(\mathrm{m}^{3} \mathrm{~s}^{-1}\right) \\
\end{array}$ & $\begin{array}{l}Q_{\max }-Q_{\mathrm{p}} \\
\left(\mathrm{m}^{3} \mathrm{~s}^{-1}\right) \\
\end{array}$ & $Q_{\max } / Q_{\mathrm{p}}$ \\
\hline 1953 & $7.30 \sim 8.13$ & 12300 & & 6000 & 6300 & 1.78 \\
\hline 1953 & $8.15 \sim 9.1$ & 8406 & & 6000 & 2410 & 1.40 \\
\hline 1954 & $8.3 \sim 8.25$ & 15000 & 34.5 & 5800 & 9200 & 2.59 \\
\hline 1954 & $8.28 \sim 9.9$ & 11000 & & 5800 & 5200 & 1.90 \\
\hline 1957 & $7.17 \sim 7.23$ & 13000 & 46.1 & 6000 & 7000 & 2.17 \\
\hline 1958 & $7.16 \sim 7.21$ & 22300 & 96.6 & 5620 & 16680 & 3.97 \\
\hline 1975 & $9.18 \sim 10.21$ & 7580 & 42.7 & 4500 & 3080 & 1.68 \\
\hline 1976 & $8.24 \sim 9.5$ & 9210 & 47 & 5510 & 3700 & 1.67 \\
\hline 1977 & $8.4 \sim 8.11$ & 10800 & 437 & 6200 & 4600 & 1.74 \\
\hline 1981 & $9.3 \sim 9.16$ & 8060 & 41.7 & 5320 & 2740 & 1.52 \\
\hline 1982 & $7.31 \sim 8.6$ & 15300 & 38.7 & 6000 & 9300 & 2.55 \\
\hline 1996 & $7.30 \sim 8.22$ & 7860 & 58.4 & 3500 & 4360 & 2.25 \\
\hline
\end{tabular}


Table 2 Characteristics of small overbank floods at Huayuankou gauging station

\begin{tabular}{|c|c|c|c|c|c|c|c|}
\hline Year & $\begin{array}{l}\text { Period } \\
\text { (mm.dd) }\end{array}$ & $\begin{array}{l}\text { Peak Discharge } \\
Q_{\max }\left(\mathrm{m}^{3} \mathrm{~s}^{-1}\right) \\
\end{array}$ & $\begin{array}{c}\text { Date } \\
\text { (mm.dd) }\end{array}$ & $\begin{array}{l}\text { Sediment concentration } \\
\left(\mathrm{kgm}^{-3}\right) \\
\end{array}$ & $\begin{array}{c}\text { Bankfull discharge } \\
Q_{\mathrm{p}}\left(\mathrm{m}^{3} \mathrm{~s}^{-1}\right) \\
\end{array}$ & $\begin{array}{l}Q_{\max }-Q_{\mathrm{p}} \\
\left(\mathrm{m}^{3} \mathrm{~s}^{-1}\right) \\
\end{array}$ & $Q_{\max } / Q_{\mathrm{p}}$ \\
\hline 1951 & $8.16 \sim 8.23$ & 9220 & 8.17 & & 7000 & 2220 & 1.32 \\
\hline 1955 & $9.8 \sim 10.5$ & 6800 & 9.19 & 41 & 6170 & 630 & 1.10 \\
\hline 1956 & $7.31 \sim 8.15$ & 8360 & 8.5 & 23.4 & 6520 & 1840 & 1.28 \\
\hline 1956 & $6.24 \sim 7.2$ & 7580 & 6.27 & 32 & 6520 & 1060 & 1.16 \\
\hline 1958 & $7.5 \sim 7.10$ & 7910 & 7.7 & 55.6 & 5620 & 2120 & 1.38 \\
\hline 1958 & $7.25 \sim 7.28$ & 7130 & 7.26 & 51 & 5620 & 1380 & 1.25 \\
\hline 1958 & $7.30 \sim 8.7$ & 8280 & 8.4 & & & & \\
\hline 1959 & $8.1 \sim 8.12$ & 7680 & 8.8 & 175 & 5700 & 1980 & 1.35 \\
\hline 1959 & $8.12 \sim 9.12$ & 9480 & 8.23 & 172 & 5700 & 3780 & 1.66 \\
\hline 1959 & $7.21 \sim 7.29$ & 6320 & 7.24 & 80 & 5700 & 620 & 1.11 \\
\hline 1964 & $7.17 \sim 8.8$ & 9430 & 7.28 & 44.7 & 8200 & 1230 & 1.15 \\
\hline 1966 & $7.21 \sim 8.14$ & 8480 & 8.1 & 134 & 6500 & 750 & 1.12 \\
\hline 1968 & $9.4 \sim 10.29$ & 7180 & 10.14 & & 6500 & 680 & 1.10 \\
\hline 1970 & $8.26 \sim 9.8$ & 5830 & 8.31 & 129 & 4900 & 930 & 1.19 \\
\hline 1971 & $7.24 \sim 7.31$ & 5040 & 7.28 & 192 & 4300 & 740 & 1.17 \\
\hline 1973 & $8.26 \sim 9.5$ & 5890 & 9.3 & 348 & 3560 & 2330 & 1.65 \\
\hline 1975 & $7.20 \sim 8.4$ & 5490 & 8.1 & 180 & 4500 & 990 & 1.22 \\
\hline 1975 & $8.4 \sim 8.20$ & 5660 & 8.10 & 31.7 & 4500 & 1160 & 1.26 \\
\hline 1977 & $7.7 \sim 7.16$ & 8100 & 7.9 & 470 & 6200 & 1900 & 1.31 \\
\hline 1977 & $8.2 \sim 8.14$ & 7320 & 8.4 & 86.9 & 6200 & 1120 & 1.18 \\
\hline 1979 & $8.10 \sim 8.22$ & 6660 & 8.14 & 108 & 5900 & 760 & 1.13 \\
\hline 1981 & $9.24 \sim 10.12$ & 7030 & 9.30 & 21.5 & 5320 & 1710 & 1.32 \\
\hline 1982 & $8.12 \sim 8.19$ & 6820 & 8.15 & 49.9 & 6000 & 820 & 1.14 \\
\hline 1983 & $7.26 \sim 8.10$ & 8180 & 8.2 & 33.6 & 6800 & 1380 & 1.20 \\
\hline 1985 & $9.14 \sim 9.24$ & 8260 & 9.17 & 52.2 & 6900 & 1360 & 1.20 \\
\hline 1988 & $8.6 \sim 8.25$ & 7000 & 8.21 & 44.9 & 5500 & 1500 & 1.27 \\
\hline 1992 & $8.10 \sim 8.19$ & 6430 & 8.16 & 245 & 4300 & 2130 & 1.50 \\
\hline 1993 & $7.31 \sim 8.14$ & 4300 & 8.7 & 143 & 3800 & 500 & 1.13 \\
\hline 1994 & $8.6 \sim 8.10$ & 6300 & 8.8 & 209 & 3700 & 2600 & 1.70 \\
\hline 1994 & $8.12 \sim 8.19$ & 5170 & 7.1 & 41.8 & 3700 & 1470 & 1.40 \\
\hline 1998 & $7.9 \sim 7.25$ & 4700 & 7.16 & 147 & 3700 & 1000 & 1.27 \\
\hline
\end{tabular}

This article is protected by copyright. All rights reserved. 
Table 3 Sedimentation during large overbank floods in the Lower Yellow River

\begin{tabular}{|c|c|c|c|c|c|c|c|c|c|}
\hline \multirow{2}{*}{ Year } & \multirow{2}{*}{$\begin{array}{l}\text { Period } \\
\text { (mm.dd) }\end{array}$} & \multicolumn{5}{|c|}{ Huayunakou station } & \multicolumn{3}{|c|}{$\begin{array}{l}\text { Sedimentation in the reach from } \\
\text { Huayuankou to Lijin stations } \\
\left.\text { (10 } 10^{8} \text { tons }\right)\end{array}$} \\
\hline & & $\begin{array}{l}\text { Peak discharge } \\
Q_{\max }\left(\mathrm{m}^{3} \mathrm{~s}^{-1}\right)\end{array}$ & $\begin{array}{l}\text { Runoff } \\
\left(10^{8} \mathrm{~m}^{3}\right)\end{array}$ & $\begin{array}{l}\text { Sediment } \\
\text { load }\left(10^{8}\right. \\
\text { metric ton })\end{array}$ & $\begin{array}{c}\text { Sediment } \\
\text { concentration } \\
\left(\mathrm{kgm}^{-3}\right)\end{array}$ & $\begin{array}{l}\text { Sediment } \\
\text { transport } \\
\text { coefficient } \\
\left(\mathrm{kg} \cdot \mathrm{s} \cdot \mathrm{m}^{-6}\right)\end{array}$ & $\begin{array}{c}\text { Bankfull } \\
\text { channel }\end{array}$ & $\begin{array}{l}\text { Flood- } \\
\text { plains } \\
\quad *\end{array}$ & $\begin{array}{c}\text { Whole } \\
\text { cross-profile }\end{array}$ \\
\hline 1953 & $7.26 \sim 8.14$ & 12320 & 68.0 & 3.0 & 44.2 & 0.011 & -3.00 & 3.03 & 0.03 \\
\hline 1953 & $8.15 \sim 9.1$ & 8406 & 45.8 & 5.8 & 126.4 & 0.043 & 1.49 & 1.03 & 2.52 \\
\hline 1954 & $8.2 \sim 8.25$ & 15000 & 123.2 & 5.9 & 47.9 & 0.010 & -2.08 & 4.90 & 2.82 \\
\hline 1954 & $8.28 \sim 9.9$ & 12300 & 64.7 & 6.3 & 97.7 & 0.017 & & & \\
\hline 1957 & $7.12 \sim 8.4$ & 13000 & 90.2 & 4.7 & 51.7 & 0.012 & -4.33 & 5.27 & 0.94 \\
\hline 1958 & $7.13 \sim 7.23$ & 22300 & 73.3 & 5.6 & 76.5 & 0.010 & -8.60 & 10.69 & 2.09 \\
\hline 1975 & $9.29 \sim 10.5$ & 7580 & 37.7 & 1.5 & 39.4 & 0.006 & -2.68 & 3.39 & 0.71 \\
\hline 1976 & $8.25 \sim 9.6$ & 9210 & 80.8 & 2.9 & 35.4 & 0.005 & -1.06 & 2.81 & 1.75 \\
\hline 1981 & $9.24 \sim 10.12$ & 7760 & 83.1 & 1.8 & 21.2 & 0.004 & -3.02 & 2.66 & -0.36 \\
\hline 1982 & $7.30 \sim 8.9$ & 15300 & 61.1 & 2.0 & 32.6 & 0.005 & -2.27 & 2.56 & 0.29 \\
\hline 1977 & $7.6 \sim 7.15$ & 8100 & 33.1 & 7.4 & 223.6 & 0.058 & 5.02 & 6.44 & 11.46 \\
\hline 1977 & $8.4 \sim 8.11$ & 10800 & 27.8 & 8.4 & 302.2 & 0.075 & & & \\
\hline 1988 & $8.11 \sim 8.26$ & 7000 & 65.1 & 5.0 & 76.7 & 0.016 & -1.30 & 1.53 & 0.23 \\
\hline 1996 & $8.3 \sim 8.15$ & 7860 & 44.6 & 3.4 & 76 & 0.019 & -1.61 & 4.45 & 2.84 \\
\hline Total & & & 898.5 & 63.6 & & & -21.19 & 46.66 & 25.48 \\
\hline
\end{tabular}

*Floodplains include both secondary and main floodplains. 
Table 4 Sedimentation in the Lower Yellow River during large overbank floods

\begin{tabular}{|c|c|c|c|c|c|c|c|c|c|c|c|c|}
\hline \multirow{2}{*}{ Year } & \multirow{2}{*}{$\begin{array}{c}\text { Period } \\
\text { (mm.dd) }\end{array}$} & \multirow{2}{*}{$\begin{array}{c}\text { Peak } \\
\text { discharge } \\
Q_{\max }\left(\mathrm{m}^{3} \mathrm{~s}^{-1}\right)\end{array}$} & \multirow{2}{*}{$\begin{array}{l}\text { Runoff } \\
\left(10^{8} \mathrm{~m}^{3}\right)\end{array}$} & \multirow{2}{*}{$\begin{array}{l}\text { Sediment } \\
\text { load } \\
\left(10^{8} \text { metric }\right. \\
\text { ton })\end{array}$} & \multirow{2}{*}{$\begin{array}{c}\text { Sediment } \\
\text { concentration } \mathrm{C} \\
\quad\left(\mathrm{kgm}^{-3}\right)\end{array}$} & \multirow{2}{*}{$\begin{array}{c}\mathrm{C} / \mathrm{Q} \\
\left(\mathrm{kgsm}^{-6}\right)\end{array}$} & \multirow{2}{*}{$\begin{array}{c}Q_{\mathrm{p}} \\
\left(\mathrm{m}^{3} \mathrm{~s}^{-1}\right)\end{array}$} & \multicolumn{5}{|c|}{ Sedimentation $\left(10^{8}\right.$ metric ton $)$} \\
\hline & & & & & & & & Bankfull channel & Floodplains & Secondary floodplain & Main floodplain & Whole cross-profile \\
\hline 1966 & $7.21 \sim 8.14$ & 8480 & 78.1 & 7.8 & 99.9 & 0.028 & 6500 & 0.93 & 0.43 & 0.33 & 0.09 & 1.36 \\
\hline 1968 & $9.4 \sim 10.29$ & 7180 & 189.8 & 5.1 & 26.9 & 0.007 & 6500 & -2.04 & 0.56 & 0.48 & 0.08 & -1.48 \\
\hline 1970 & $8.26 \sim 9.8$ & 5580 & 38.1 & 4.13 & 108.4 & 0.034 & 4900 & 0.01 & 1.33 & 1.15 & 0.18 & 1.34 \\
\hline 1971 & $7.26 \sim 7.30$ & 3910 & 9.9 & 1.39 & 140.4 & 0.061 & 4300 & 1.25 & 0.57 & 0.56 & 0.01 & 1.82 \\
\hline 1972 & $9.1 \sim 9.8$ & 4030 & 17.5 & 0.7 & 40.0 & 0.016 & 4110 & -1.05 & 0.70 & 0.63 & 0.07 & -0.34 \\
\hline 1973 & $8.26 \sim 9.5$ & 5050 & 31.8 & 6.98 & 219.5 & 0.066 & 3560 & 0.81 & 2.86 & 2.56 & 0.31 & 3.67 \\
\hline 1983 & $7.29 \sim 8.10$ & 7580 & 55.4 & 1.33 & 24.0 & 0.005 & 6800 & -0.24 & 0.35 & 0.32 & 0.03 & 0.1 \\
\hline 1985 & $9.15 \sim 9.24$ & 7920 & 43.1 & 1.77 & 41.1 & 0.008 & 6900 & -0.92 & 0.58 & 0.57 & 0.02 & -0.33 \\
\hline 1989 & $7.23 \sim 7.27$ & 5480 & 14.1 & 1.73 & 122.7 & 0.038 & 6000 & 0.53 & 0.60 & 0.6 & 0.00 & 1.13 \\
\hline 1992 & $8.10 \sim 8.19$ & 4850 & 24.9 & 4.54 & 182.3 & 0.063 & 4300 & 2.99 & 1.65 & 1.65 & 0.00 & 4.64 \\
\hline 1994 & $8.6 \sim 8.10$ & 6300 & 11.4 & 2.4 & 210.5 & 0.080 & 3700 & \multirow{2}{*}{2.50} & \multirow{2}{*}{0.68} & \multirow{2}{*}{0.65} & \multirow{2}{*}{0.03} & 1.59 \\
\hline 1994 & $8.12 \sim 8.19$ & 5170 & 17.9 & 3.2 & 178.8 & 0.069 & 3700 & & & & & 1.60 \\
\hline
\end{tabular}

This article is protected by copyright. All rights reserved. 
Table 5 Average annual sedimentation in the Lower Yellow River

\begin{tabular}{|c|c|c|c|c|c|c|}
\hline \multirow{2}{*}{ Reach } & \multicolumn{3}{|c|}{$\begin{array}{l}\text { Average annual sedimentation } \\
\qquad\left(10^{9} \mathrm{~m}^{3}\right)\end{array}$} & \multicolumn{3}{|c|}{$\begin{array}{c}\text { Percentage } \\
(\%)\end{array}$} \\
\hline & $\begin{array}{l}\text { Bankfull } \\
\text { channel }\end{array}$ & Floodplains & $\begin{array}{l}\text { Whole } \\
\text { cross-profile }\end{array}$ & $\begin{array}{l}\text { Bankfull } \\
\text { channel }\end{array}$ & Floodplains & $\begin{array}{l}\text { Whole } \\
\text { cross-profile }\end{array}$ \\
\hline Xiaolangdi-Huayuankou & 0.44 & 0.21 & 0.66 & 67 & 33 & 100 \\
\hline Huayuankou-Gaocun & 0.21 & 0.76 & 0.98 & 22 & 78 & 100 \\
\hline Gaocun-Aishan & 0.14 & 0.70 & 0.84 & 16 & 84 & 100 \\
\hline Aishan-Lijin & 0.01 & 0.31 & 0.32 & 2 & 98 & 100 \\
\hline Total & 0.80 & 1.99 & 2.79 & 29 & 71 & 100 \\
\hline
\end{tabular}


Table 6 Distribution of sedimentation in different reaches of the Lower Yellow River during sub-periods from 1965 to 1999

\begin{tabular}{|c|c|c|c|c|c|c|c|c|c|c|}
\hline \multirow[b]{2}{*}{ Period } & \multirow[b]{2}{*}{ Reach* } & \multicolumn{5}{|c|}{ Sedimentation $\left(10^{9} \mathrm{~m}^{3}\right)$} & \multicolumn{4}{|c|}{ Percentage $(\%)$} \\
\hline & & $\begin{array}{c}\text { Bankf } \\
\text { ull } \\
\text { chann } \\
\text { el }\end{array}$ & $\begin{array}{l}\text { Secondar } \\
\text { y } \\
\text { floodplain }\end{array}$ & $\begin{array}{l}\text { Between two } \\
\text { secondary } \\
\text { dikes }\end{array}$ & $\begin{array}{c}\text { Main } \\
\text { floodplain }\end{array}$ & $\begin{array}{l}\text { Whole } \\
\text { Cross-p } \\
\text { rofile }\end{array}$ & $\begin{array}{c}\text { Bankfu } \\
11 \\
\text { channe } \\
1\end{array}$ & $\begin{array}{l}\text { Secondar } \\
\text { y } \\
\text { floodplai } \\
\text { n }\end{array}$ & $\begin{array}{l}\text { Between two } \\
\text { secondary } \\
\text { dikes }\end{array}$ & $\begin{array}{c}\text { Main } \\
\text { floodplai } \\
\mathrm{n}\end{array}$ \\
\hline & XLD-HYK & 4.27 & 0.4 & 4.67 & 0.11 & 4.78 & 89 & 8 & 98 & 2 \\
\hline & HYK-GC & 9.11 & 1.44 & 10.55 & 0.93 & 11.48 & 79 & 13 & 92 & 8 \\
\hline $1965-1973$ & GC-AS & 4.41 & 0.1 & 4.51 & 0.07 & 4.58 & 96 & 2 & 98 & 2 \\
\hline & AS-LJ & 2.87 & 0 & 2.87 & 0 & 2.87 & 100 & 0 & 100 & 0 \\
\hline & Subtotal & 20.66 & 1.93 & 22.59 & 1.12 & 23.71 & 87 & 8 & 95 & 5 \\
\hline & XLD-HYK & -3.47 & -0.54 & -4 & 0.21 & -3.8 & 91 & 14 & 105 & -5 \\
\hline & HYK-GC & -1.37 & 0.93 & -0.44 & 2.11 & 1.66 & -82 & 56 & -27 & 127 \\
\hline $1974-1985$ & GC-AS & 1.18 & 1.42 & 2.6 & 2 & 4.6 & 26 & 31 & 57 & 43 \\
\hline & AS-LJ & -0.79 & 0.18 & -0.62 & 1.81 & 1.19 & -66 & 15 & -52 & 152 \\
\hline & Subtotal & -4.45 & 1.99 & -2.46 & 6.13 & 3.67 & -121 & 54 & -67 & 167 \\
\hline & XLD-HYK & 4.18 & 0.62 & 4.8 & 0.38 & 5.18 & 81 & 12 & 93 & 7 \\
\hline & HYK-GC & 8.48 & 1.02 & 9.5 & 0.6 & 10.1 & 84 & 10 & 94 & 6 \\
\hline 1986-1999 & GC-AS & 3.17 & 0.06 & 3.23 & 0.09 & 3.32 & 96 & 2 & 97 & 3 \\
\hline & AS-LJ & 3.3 & -0.03 & 3.27 & 0.52 & 3.79 & 87 & -1 & 86 & 14 \\
\hline & Subtotal & 19.13 & 1.66 & 20.8 & 1.58 & 22.38 & 85 & 7 & 93 & 7 \\
\hline & XLD-HYK & 4.98 & 0.48 & 5.47 & 1.10 & 6.57 & 76 & 7 & 83 & 17 \\
\hline & HYK-GC & 16.21 & 3.38 & 19.6 & 3.64 & 23.24 & 70 & 15 & 84 & 16 \\
\hline 1965-1999 & GC-AS & 8.76 & 1.58 & 10.34 & 2.16 & 12.5 & 70 & 13 & 83 & 17 \\
\hline & AS-LJ & 5.38 & 0.14 & 5.52 & 2.27 & 7.79 & 69 & 2 & 71 & 29 \\
\hline & Subtotal & 35.34 & 5.59 & 40.93 & 9.17 & 50.10 & 71 & 11 & 82 & 18 \\
\hline
\end{tabular}

*The full names of the reaches are given in the caption of Fig. 11. 
Table 7 Sedimentation rates in different reaches of the Lower Yellow River

\begin{tabular}{|c|c|c|c|c|c|c|c|c|}
\hline \multirow[b]{2}{*}{ Reach* } & \multicolumn{4}{|c|}{ Width of sedimentation (m) } & \multicolumn{4}{|c|}{ Sedimentation rates $(\mathrm{m} / \mathrm{y})$} \\
\hline & $\begin{array}{l}\text { Active } \\
\text { channel }\end{array}$ & $\begin{array}{l}\text { Bankfull } \\
\text { channel }\end{array}$ & $\begin{array}{l}\text { Secondary } \\
\text { floodplain }\end{array}$ & $\begin{array}{c}\text { Main } \\
\text { floodplain }\end{array}$ & $\begin{array}{l}\text { Active } \\
\text { channel }\end{array}$ & $\begin{array}{l}\text { Bankfull } \\
\text { channel }\end{array}$ & $\begin{array}{l}\text { Secondary } \\
\text { floodplain }\end{array}$ & $\begin{array}{c}\text { Main } \\
\text { floodplain }\end{array}$ \\
\hline XLD-HYK & 600 & 3794 & 1142 & 4381 & 0.021 & 0.029 & 0.009 & 0.005 \\
\hline HYK- & 600 & 3412 & 1526 & 3809 & 0.077 & 0.078 & 0.037 & 0.016 \\
\hline GC-AS & 600 & 1445 & 605 & 2359 & 0.101 & 0.092 & 0.039 & 0.014 \\
\hline AS-LJ & 600 & 743 & 33 & 1795 & 0.090 & 0.076 & 0.045 & 0.013 \\
\hline Average & 600 & 1811 & 618 & 2689 & 0.078 & 0.073 & 0.034 & 0.013 \\
\hline
\end{tabular}

*The full names of the reaches are given in the caption of Fig. 11.
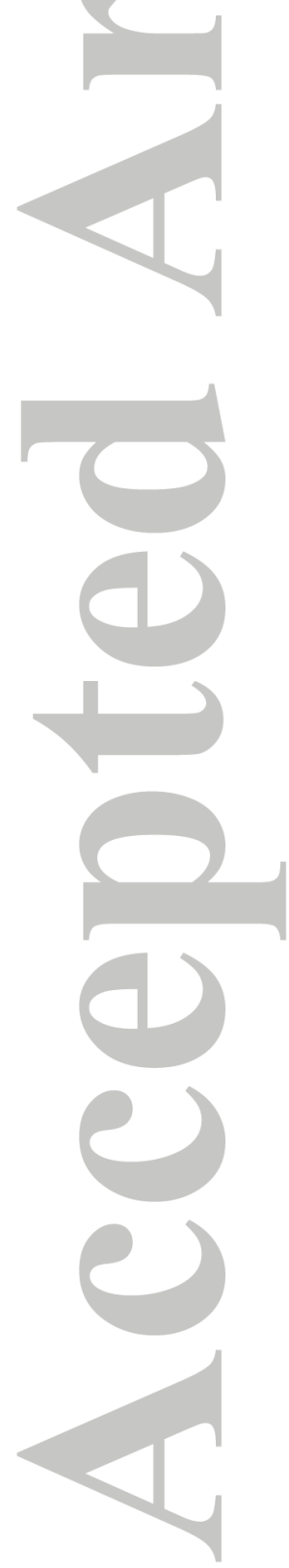